\title{
Heat stress effects on the cumulus cells surrounding the bovine oocyte during maturation: altered matrix metallopeptidase 9 and progesterone production
}

\author{
L A Rispoli, R R Payton, C Gondro', A M Saxton, K A Nagle, B W Jenkins, F N Schrick and \\ J L Edwards
}

Department of Animal Science, Institute of Agriculture, University of Tennessee, UT AgResearch, 251 Brehm Animal Science Building, 2506 River Drive, Knoxville, Tennessee 37996-4574, USA and ${ }^{1}$ School of Environmental and Rural Science, The Centre for Genetic Analysis and Applications, University of New England, Armidale, New South Wales 2351, Australia

Correspondence should be addressed to J L Edwards; Email: jedwards@utk.edu

\begin{abstract}
When the effects of heat stress are detrimental during maturation, cumulus cells are intimately associated with the oocyte. To determine the extent to which heat stress affects these cells, in this study, transcriptome profiles of the cumulus that surrounded control and heat-stressed oocytes $\left(41^{\circ} \mathrm{C}\right.$ during the first $12 \mathrm{~h}$ only and then shifted back to $\left.38.5^{\circ} \mathrm{C}\right)$ during in vitro maturation (IVM) were compared using Affymetrix bovine microarrays. The comparison of cumulus-derived profiles revealed a number of transcripts whose levels were increased $(n=11)$ or decreased $(n=13) \geq$ twofold after heat stress exposure $(P<0.01)$, sufficient to reduce the development of blastocysts by $46.4 \%$. In a separate study, quantitative PCR (qPCR) was used to confirm heat-induced differences in the relative abundances of the transcripts of five different genes (caveolin 1, matrix metallopeptidase 9, FSH receptor, Indian hedgehog homolog, and inducible nitric oxide synthase). Heat stress exposure resulted in $>1.7$-fold decrease in the protein levels of latent matrix metallopeptidase 9 (proMMP9). Heat-induced reductions in transcript levels were noted at $6 \mathrm{~h}$ IVM with reductions in proMMP9 protein levels at $18 \mathrm{~h} \mathrm{IVM}(P=0.0002)$. Independent of temperature, proMMP9 levels at $24 \mathrm{~h}$ IVM were positively correlated with the development rate of blastocysts $\left(R^{2}=0.36 ; P=0.002\right)$. The production of progesterone increased during maturation; heat-induced increases were evident by $12 \mathrm{~h} \mathrm{IVM}(P=0.002)$. Both MMP9 and progesterone are associated with the developmental competence of the oocyte; thus, it seems plausible for some of the negative consequences of heat stress on the cumulus-oocyte complex to be mediated through heat-induced perturbations occurring in the surrounding cumulus.
\end{abstract}

Reproduction (2013) 146 193-207

\section{Introduction}

Hyperthermia-induced reductions in fertility in bovine species are related to i) alterations in the maternal environment (i.e. endocrine-mediated or other; reviewed by Rensis \& Scaramuzzi (2003)) and ii) direct negative effects of elevated temperatures on the oocyte and early embryo (Edwards \& Hansen 1996, 1997, Edwards et al. 2001). Marked changes occurring in the nucleus and ooplasm during maturation explain why maturing oocytes are susceptible to the direct effects of heat stress (Edwards \& Hansen 1996, Roth \& Hansen 2004, Edwards et al. 2005, Schrock et al. 2007).

When the effects of heat stress are most detrimental to the competence of maturing oocytes to develop to the blastocyst stage after fertilization (i.e. during the first 10-12 h of maturation (Putney et al. 1989, Edwards \& Hansen 1996)), the surrounding cumulus cells are intimately associated with the oocyte. To this end, numerous cytoplasmic projections extend from the cumulus cells through the zona pellucida penetrating the oolemma sufficiently to form gap junctional complexes (Hyttel et al. 1986a, 1986b). Gap junctional complexes between the cumulus and oolemma effectively permit a bidirectional exchange of small metabolic substrates (e.g. choline) and second messengers (e.g. cAMP), whereas the transfer of larger molecules (e.g. KIT ligand) may occur through secretion and receptormediated endocytosis (reviewed by Kidder \& Vanderhyden (2010)). Even though gap junctional complexes break down during maturation (Hyttel et al. 1986a, 1986b), the surrounding cumulus cells encase the oocyte in an extracellular matrix, which plays a key role in ovulation and subsequent fertilization (reviewed by Russell \& Robker (2007)).

The presence of cumulus cells is essential for progression to metaphase II and acquisition of embryonic competence. For instance, the removal of cumulus before 
maturation impairs the progression to metaphase II and development of blastocysts (Zhang et al. 1995, Geshi et al. 2000). Culture of denuded bovine oocytes in the presence of a dispersed cumulus or a monolayer is not sufficient to restore the developmental competence (Zhang et al. 1995, Luciano et al. 2005). Rather, improved competence of denuded oocytes to develop into blastocysts after fertilization has been shown to be dependent on the co-presence of intact cumulus-oocyte complexes at the beginning and through the end of maturation and IVF, suggesting the importance of cumulus-derived secreted factors (Luciano et al. 2005).

Unlike the oocyte, cumulus cells are transcriptionally active (Regassa et al. 2011) and are capable of undergoing a heat shock response (Payton et al. 2011). In porcine species, the effects of heat stress on maturation rates only occurred when cumuli were present (Yuan et al. 2008). Prolonged heat stress exposure in bovine species $\left(2.5^{\circ} \mathrm{C}\right.$ above the normal body temperature for $24 \mathrm{~h}$ ) reduced the production of hyaluronan and impaired the expansion of cumulus (Lenz et al. 1983). In the mouse, heat stress exposure $\left(1.5^{\circ} \mathrm{C}\right.$ above the normal body temperature for $6 \mathrm{~h}$ ) after reaching maturity (i.e. metaphase II stage) accelerated the aging of oocytes, presumably by increasing the production of an aging-promoting factor by cumulus cells (Qiao et al. 2008).

Mindful that cumulus cells are affected by heat stress and essential for the acquisition of embryonic competence after fertilization, we hypothesized that some of the deleterious effects of heat stress on the cumulusoocyte complex reducing the development of blastocysts may be mediated through heat-induced perturbations occurring in the surrounding cumulus. To determine the extent to which this may be occurring, transcriptome profiles of the cumulus that surrounded the control and heat-stressed oocytes (heat stress applied at $41^{\circ} \mathrm{C}$ during the first $12 \mathrm{~h}$ only and then shifted back to $38.5^{\circ} \mathrm{C}$ ) during in vitro maturation (IVM) were compared using Affymetrix bovine microarrays. Performing IVF on subsets of cumulus-oocyte complexes allowed assessment of the extent to which cumulus-derived changes related to changes in the competence of the oocytes enveloped therein allowed them to develop to the blastocyst stage. The obtained results prompted a closer examination of heat-induced perturbations in the production of matrix metallopeptidase 9 (MMP9) and progesterone by the control and heat-stressed cumulusoocyte complexes during maturation.

\section{Materials and methods}

\section{Transcriptome profiles of the cumulus surrounding the control and heat-stressed oocytes}

Intact cumulus-oocyte complexes underwent IVM at 38.5 (control) or $41{ }^{\circ} \mathrm{C}$ (heat stress applied during the first $12 \mathrm{~h}$ only and then shifted back to $38.5^{\circ} \mathrm{C}$ ) as shown in Fig. 1. After $24 \mathrm{~h}$

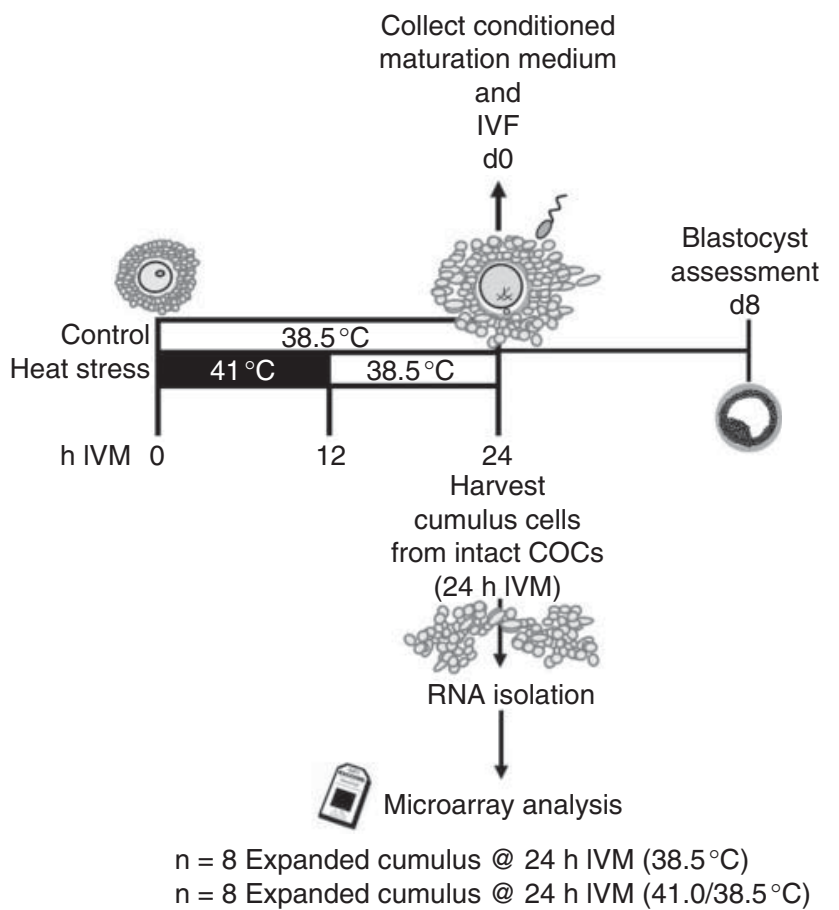

Figure 1 Experimental design and endpoints for evaluating the transcriptome profiles of the cumulus surrounding the control and heatstressed oocytes. Intact cumulus-oocyte complexes (COCs) underwent IVM at $38.5^{\circ} \mathrm{C}$ (control) or $41^{\circ} \mathrm{C}$ (heat stress applied during the first $12 \mathrm{~h}$ only and then shifted back to $38.5^{\circ} \mathrm{C}$ ). After a total of $24 \mathrm{~h}$ of IVM (h IVM), the surrounding cumulus was harvested; pelleted cells were maintained separately based on the treatment and lysed in RNA extraction buffer. Thereafter, RNA was isolated for the microarray analysis. Before performing IVF on other subsets of control and heatstressed cumulus-oocyte complexes, the conditioned maturation medium was collected and stored at $-20^{\circ} \mathrm{C}$. The development of blastocysts was assessed 8 days after IVF. This experiment was replicated eight different times using 16 microarray chips in total.

of IVM (h IVM), the surrounding cumulus was harvested by vortexing cumulus-oocyte complexes for $4 \mathrm{~min}$ in a $0.3 \%$ hyaluronidase HEPES-buffered medium. Pelleted cumulus cells originating from 60 cumulus-oocyte complexes, devoid of any denuded oocytes and maintained separately according to the treatment, were lysed in an RNA extraction buffer (Molecular Devices, Sunnyvale, CA, USA) and stored at $-80^{\circ} \mathrm{C}$. Conditioned maturation medium resulting from the culture of control and heat-stressed cumulus-oocyte complexes (35-50 per $500 \mu \mathrm{l}$ medium) was stored at $-20^{\circ} \mathrm{C}$. Other subsets of control and heat-stressed cumulus-oocyte complexes (35-50 per $500 \mu$ I IVM medium) underwent IVF using Percoll-prepared frozen-thawed semen (pool of two bulls; 500000 motile sperm $/ \mathrm{ml}$ ) and were allowed to develop to the blastocyst stage as described by Edwards et al. (2009) to document the extent to which heat stress reduced the developmental competence of the oocyte enveloped within the cumulus cells. The development of blastocysts was assessed 8 days after IVF.

To provide a more precise test of the hypothesis (i.e. some of the deleterious effects of heat stress on the cumulus-oocyte 
complex reducing the development of blastocysts may be mediated through heat-induced perturbations occurring in the surrounding cumulus), RNA isolation was limited to cumulus samples from those experimental replicates $(n=8)$ whereby heat stress exposure during oocyte maturation reduced the development of blastocysts by $\geq 20 \%$ (PicoPure RNA isolation kit, Molecular Devices). After TURBO DNAse treatment (Applied Biosystems/Ambion, Austin, TX, USA), DNA-free total RNA (25 ng) was amplified (Ovation RNA Amplification System V2 kit, NuGEN Technologies, Inc., San Carlos, CA, USA). The resulting CDNA was hybridized to GeneChip Bovine Genome Arrays (Affymetrix, Inc., Santa Clara, CA, USA) and scanned using the GeneChip Scanner 3000 7G with AutoLoader and the Affymetrix GeneChip Command Console.

Cumulus-oocyte complexes were harvested from antral follicles ( $\sim 3$ to $10 \mathrm{~mm}$ ) as described previously (Payton et al. 2011) from abattoir-derived ovaries between the months of January and May and October through December (Brown Packing Company, Gaffney, SC, USA). This experiment was replicated using eight different batches of cumulus-oocyte complexes collected on different occasions (16 total microarray chips) utilizing a total of 2279 cumulus-oocyte complexes (960 were utilized for transcriptome profiling and 1139 for developmental controls).

\section{Relative abundance of certain transcripts (CAV1, MMP9, FSHR, IHH, and NOS2) in the cumulus surrounding the control and heat-stressed oocytes using quantitative PCR (qPCR)}

To validate some of the microarray results, the relative abundance of five transcripts identified as differentially expressed in the cumulus surrounding the control and heatstressed oocytes was examined using cumulus-derived cDNA from a different experimental effort described by Payton et al.
(2011). In that study, intact cumulus-oocyte complexes were randomly allotted to culture at $38.5^{\circ} \mathrm{C}$ for 0 (i.e. soon after the removal of follicles, but before placement into the IVM medium), 12, or $24 \mathrm{~h}$ IVM. Other subsets of intact cumulusoocyte complexes were cultured at $41.0^{\circ} \mathrm{C}$ for $12 \mathrm{~h}$ IVM and removed for analysis or cultured for another $12 \mathrm{~h}$ after switching from 41.0 to $38.5{ }^{\circ} \mathrm{C}$. At the designated time periods, the surrounding cumulus was harvested by vortexing intact control and heat-stressed cumulus-oocyte complexes (60 per treatment group). The pelleted cumulus cells, devoid of any denuded oocytes, were maintained separately according to the origin of treatment and lysed in RNA extraction buffer for eventual RNA isolation and RT as described by Payton et al. (2011). Other subsets of control and heat-stressed cumulusoocyte complexes underwent IVF ( 50 per $500 \mu$ l medium) using Percoll-prepared frozen-thawed semen and were allowed to develop to the blastocyst stage to document the extent to which heat stress reduced the developmental competence of the oocyte enveloped within the cumulus cells. The development of blastocysts was assessed 8 days after IVF.

To evaluate the relative abundance of caveolin 1 (CAV1), $M M P 9$, FSH receptor $(F S H R)$, Indian hedgehog homolog $(I H H)$, and nitric oxide synthase 2 (NOS2) transcripts, primer sets were designed using the FastPCR software (ver 4.0.27; Kalendar et al. 2009) based on the $5^{\prime}$ and $3^{\prime}$ ends of transcripts when feasible (Table 1). The efficiencies of primer sets were between 90 and $110 \%$. To ensure specificity, PCR products were sequenced. Each qPCR contained $100 \mathrm{pg}$ of total RNA and was subjected to $50{ }^{\circ} \mathrm{C}(2 \mathrm{~min}), 95^{\circ} \mathrm{C}(10 \mathrm{~min})$, followed by 40 cycles of denaturation for $15 \mathrm{~s}\left(95^{\circ} \mathrm{C}\right)$, annealing for $30 \mathrm{~s}$ (see Table 1 for temperatures), and extension for $30 \mathrm{~s}\left(72{ }^{\circ} \mathrm{C}\right)$, followed by the construction of a dissociation curve. Data were normalized to a calibrator sample using the $\Delta \Delta C$ t method and correction with GFP as an exogenous control for loading (7300 System SDS RQ

Table 1 Sequences of primers and annealing conditions used for quantitative PCR analyses.

\begin{tabular}{|c|c|c|c|c|c|}
\hline Gene symbol & Entrez number & $\begin{array}{c}\text { Amplicon } \\
\text { location (bp) }\end{array}$ & Primer sets & $\begin{array}{c}\text { Annealing } \\
\text { temperature }\left({ }^{\circ} \mathrm{C}\right)\end{array}$ & $\begin{array}{c}\text { Primer } \\
\text { concentration }(\mathrm{nM}) \\
\end{array}$ \\
\hline CAV1 & 281040 & $80-217$ & $\begin{array}{l}\text { 5'-CGTAGACTCAGAGGGACATCTC } \\
\text { 3'-ACCAGATCTCCTTGGTGTGC }\end{array}$ & 55 & 200 \\
\hline \multirow[t]{2}{*}{ FSHR } & 281172 & $194-357$ & $\begin{array}{l}\text { 5'-CTCCCCAGGGATGCAGTCGA } \\
3^{\prime} \text {-TGTAGTTTGGGCAGGTTGGA }\end{array}$ & 55 & 400 \\
\hline & & 2115-2245 & $\begin{array}{l}\text { 5'-ACACACTTATCCCCCTAAGAC } \\
\text { 3'-AGTGGAAGTGCTCTGTCAGC }\end{array}$ & 55 & 200 \\
\hline \multirow[t]{2}{*}{$I H H$} & 522714 & $57-157$ & $\begin{array}{l}\text { 5'-CCAACTACAATCCAGACATCATCTTC } \\
\text { 3'-GATGGCCAGCGAGTTCAGGC }\end{array}$ & 60 & 200 \\
\hline & & 1432-1552 & $\begin{array}{l}\text { 5'-CCACACTCCTCGGGACACATACG } \\
\text { 3'-CCACACTCCTCGGGACACATACG }\end{array}$ & 60 & 400 \\
\hline \multirow[t]{2}{*}{ NOS2 } & 282876 & $307-425$ & $\begin{array}{l}\text { 5'-AAGGCCAAAGGGGATCTCTC } \\
\text { 3'-TGAGGTAGAAGCTCGTCTGG }\end{array}$ & 55 & 200 \\
\hline & & $3578-3699$ & $\begin{array}{l}5^{\prime} \text {-ССССАТСТССТТСССТСТСАААСС } \\
3^{\prime} \text {-GAGGССАGТTTСТССАССАСС }\end{array}$ & 55 & 600 \\
\hline$M M P 2^{\mathrm{a}}$ & 282872 & 1729-2132 & $\begin{array}{l}\text { 5'-ACGAAGACCCACAGGAGGAG } \\
3^{\prime} \text {-CAGCCAATCGGATTTGATGC }\end{array}$ & 56 & 400 \\
\hline$M M P 9^{b}$ & 282871 & $482-554$ & $\begin{array}{l}\text { 5'-TGTACGGCCCCGAAGCT } \\
\text { 3'-GGATCGAAGGGATACCCATCT }\end{array}$ & 56 & 400 \\
\hline $18 \mathrm{~S} r \mathrm{rNA}^{\mathrm{c}}$ & 493779 & 980-1079 & $\begin{array}{l}\text { 5'-AAGACGGACCAGAGCGAAAG } \\
3^{\prime} \text {-GGTCGGAACTACGACGGTATCT }\end{array}$ & 60 & 200 \\
\hline$G F P^{c}$ & - & - & $\begin{array}{l}\text { 5'-CAACTTCAAGACCCGCCACA } \\
\text { 3'-TCTGGTAAAAGGACAGGGCCA }\end{array}$ & - & 800 \\
\hline
\end{tabular}

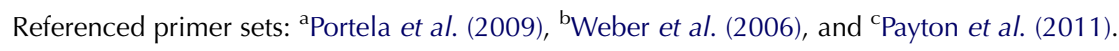


Study Software, ver 1.3; Applied Biosystems). The calibrator for the FSHR, IHH, and NOS2 transcripts was set to the 0-h IVM cumulus sample within each experimental replicate. CAV1 and MMP9 transcripts were not detected in the 0-h IVM cumulus samples, thus the calibrator was set to the 12 -h IVM and $38.5^{\circ} \mathrm{C}$ cumulus for these samples. Cumulus-derived cDNA was obtained from the cumulus of cumulus-oocyte complexes collected on nine different occasions using a total of 3696 cumulus-oocyte complexes (2640 were utilized for qPCR and 1056 for developmental controls).

\section{Production of MMPs (MMP9 and MMP2) by the control and heat-stressed cumulus-oocyte complexes}

The levels of proMMP9 and MMP2 were first examined in the conditioned maturation medium harvested at $24 \mathrm{~h}$ IVM and originating after the culture of intact control and heat-stressed cumulus-oocyte complexes (35-50 per 500 $\mu$ I IVM medium), whereby the cumuli were utilized for transcriptome profiling (Fig. 1). To examine the repeatability of heat-induced reductions in proMMP9 levels observed in the conditioned maturation medium at $24 \mathrm{~h}$ IVM, an additional study was conducted. To this end, the conditioned maturation medium was collected after the culture of control and heat-stressed cumulus-oocyte complexes for 24 h IVM (38 to 60 per $500 \mu \mathrm{l}$ IVM medium). This study was replicated on 12 different occasions (i.e. days with two different conditioned medium samples per treatment group) using a total of 2335 cumulusoocyte complexes.

The relative levels of proMMP9 and MMP2 were assessed using gelatin zymography as described by Toth \& Fridman (2001) with the following modifications. After assessing protein concentration (FluoroProfile protein quantification kit; Sigma Chemical Co.), the conditioned maturation medium was diluted with the Tris-glycine-SDS sample buffer (final concentration $1 \mu \mathrm{g} / \mu \mathrm{l})$. The samples were incubated at room temperature for $10 \mathrm{~min}$ before loading $20 \mu \mathrm{g}$ onto $7.5 \%$ polyacrylamide- $0.1 \%(\mathrm{w} / \mathrm{v})$ gelatin gels. The gels were run for $\sim 2.5 \mathrm{~h}$ at $125 \mathrm{~V}$ and then developed for $18 \mathrm{~h}$ at $37^{\circ} \mathrm{C}$. Dried Coomassie-stained gels were scanned at $600 \mathrm{dpi}$ resolution, and the resulting images were analyzed using ImageJ (ver 1.42q; Rasband 1997-2012) as described by Leber \& Balkwill (1997). To discriminate between latent and active forms of MMPs, unconditioned and conditioned maturation media were subjected to treatment with $1 \mathrm{mM}$ p-aminophenylmercuric acetate (APMA) for $1 \mathrm{~h}$ at $37^{\circ} \mathrm{C}$ before gelatin zymography. Latent forms of recombinant human matrix metallopeptidase 2 (proMMP2) and matrix metallopeptidase 9 (proMMP9) enzymes (AnaSpec, San Jose, CA, USA) were used as standards.

\section{Production of MMPs (MMP9 and MMP2) and progesterone during IVM of cumulus-oocyte complexes at 38.5 or $41.0^{\circ} \mathrm{C}$}

Intact cumulus-oocyte complexes underwent IVM for $24 \mathrm{~h}$ at $38.5^{\circ} \mathrm{C}$ (control) or $41.0^{\circ} \mathrm{C}$ (heat stress applied during the first $12 \mathrm{~h}$ only and then shifted back to $38.5^{\circ} \mathrm{C}$ ). Subsets (35-40 per treatment group) were removed from culture at $0,6,12,18$, and $24 \mathrm{~h}$ IVM and lysed in an extraction buffer (RNeasy Mini Kit; Qiagen) before storage at $-80{ }^{\circ} \mathrm{C}$. The associated conditioned maturation medium was collected, maintained separately based on treatment and h IVM, and stored at $-20^{\circ} \mathrm{C}$. Total RNA was isolated and treated with TURBO DNAse (Ambion) as per the manufacturer's instructions. Before qPCR, total RNA from each sample was reverse transcribed in the absence of MMLV enzyme and subjected to qPCR using 18S rRNA primers to ensure the lack of genomic DNA contamination. Genomic DNA-free total RNA (250 ng) was spiked with GFP cRNA (250 pg) before adding oligo d(T) primers (500 ng; Promega Corporation), 200 units of MMLV reverse transcriptase (Promega), $500 \mathrm{nM}$ dNTPs (Thermo Fisher Scientific, Waltham, MA, USA), and 25 units SUPERase In (Ambion) in $1 \times$ MMLV buffer $(25 \mu$ l final volume). RT was performed at $37^{\circ} \mathrm{C}$ for $1 \mathrm{~h}$ followed by heat inactivation at $94{ }^{\circ} \mathrm{C}$ for $10 \mathrm{~min}$. The relative abundance of MMP9 and MMP2 transcripts was assessed using qPCR as described above; the 6-h IVM cumulus sample, within each replicate, was set as the calibrator. The levels of secreted MMP9 and MMP2 were evaluated in the conditioned maturation medium using gelatin zymography as described above. The amounts of progesterone were measured using a solid-phase RIA (Seals et al. 1998); the sensitivity of the assay was $0.02 \mathrm{ng} / \mathrm{ml}$, and the inter- and intra-assay coefficients of variation were 7.6 and $6.0 \%$ respectively. This study was replicated on four different occasions (two different conditioned medium pools per treatment group per day) using a total of 2349 cumulusoocyte complexes.

\section{Statistical analyses}

Microarrays were assessed through standard quality control measures for Affymetrix arrays. All quality control measures (preprocessing and analyses) were performed using the statistical computing language $\mathrm{R}$ ( $\mathrm{R}$ Development Core Team, 2012, version 2.15.1) and Bioconductor (Gentleman et al. 2004). The intensities of the transcripts were estimated from the probe level data in the log2 scale using three normalization methods: variance stabilization normalization (VSN) (Huber et al. 2002), robust multi-array average (RMA) (Irizarry et al. 2003), and GCRMA (Wu et al. 2004). Data were filtered to remove any probes called marginal or absent on all the arrays and the Affymetrix control probes. Differential expression was tested for each normalization method using Limma (ver 3.14.1; Smyth 2004). Only probes having a $P$ value $<0.01$ and a fold change of at least 2 and called present for at least half of the arrays were considered significant. The intersection of the lists produced by each normalization method was used to generate the list of differentially expressed transcripts. This approach increases the stringency of the study, improves robustness to experimental noise, and reduces the false discovery rate (FDR); thus, no FDR correction method for multiple testing is necessary. Annotation of the probes was performed using an $\mathrm{R}$ annotation package derived from Bos taurus build 6.0. Overrepresented gene ontology (GO) terms were identified $(P \leq 0.05$; based on the number of significant transcripts vs the number expected of the total number of annotated transcripts within each GO term). Similarly, 
Table 2 List of transcripts differently expressed in the cumulus after $24 \mathrm{~h}$ of in vitro maturation of cumulus-oocyte complexes at 38.5 vs $41.0{ }^{\circ} \mathrm{C}$ (heat stress applied during the first $12 \mathrm{~h}$ only and then shifted back to $38.5^{\circ} \mathrm{C}$ ) as detected by the microarray analysis.

\begin{tabular}{|c|c|c|c|c|}
\hline Gene name & Symbol & Entrez number & $\begin{array}{l}\text { Affymetrix } \\
\text { probeset ID }\end{array}$ & Average fold change $^{a}$ \\
\hline \multicolumn{5}{|l|}{ Increased in heat-stressed cumulus } \\
\hline Fetal and adult testis expressed 1 & FATE1 & 281153 & Bt.5914.1.S1 & 3.78 \\
\hline $\begin{array}{l}\text { Wingless-type MMTV integration site } \\
\text { family, member } 2 B\end{array}$ & WNT2B & 445420 & Bt.27254.1.A1 & 3.05 \\
\hline \multirow[t]{2}{*}{ Vanin 1} & VNN1 & 526704 & Bt.28243.1.S1 & 3.03 \\
\hline & & & Bt.28243.2.S1 & 2.64 \\
\hline Aarachidonate lipoxygenase, epidermal & ALOX12E & 787450 & Bt.8917.1.S1 & 2.91 \\
\hline Orosomucoid 1 & ORM1 & 497200 & Bt.2490.1.A1 & 2.77 \\
\hline Actin, $\alpha-1$, skeletal muscle & ACTA1 & 281592 & Bt.8435.1.S1 & 2.70 \\
\hline Nitric oxide synthase 2 , inducible & NOS2 & 282876 & Bt.8479.1.A1 & 2.67 \\
\hline Indian hedgehog homolog (Drosophila) & IHH & 522714 & Bt.22104.1.S1 & 2.66 \\
\hline Fibromodulin & FMOD & 281168 & Bt.3797.1.S1 & 2.64 \\
\hline FSH receptor & FSHR & 281172 & Bt.4919.1.S1 & 2.53 \\
\hline $\begin{array}{l}\text { Carbohydrate }(\mathrm{N} \text {-acetylglucosamine } 6-\mathrm{O}) \\
\text { sulfotransferase } 7\end{array}$ & CHST7 & 540357 & Bt.13912.1.S1 & 2.43 \\
\hline \multicolumn{5}{|l|}{ Decreased in heat-stressed cumulus } \\
\hline Not assigned & & 767920 & Bt.2577.1.S1 & -2.17 \\
\hline Trophoblast Kunitz domain protein 1-like & LOC618696 & 618696 & Bt.26365.1.A1 & -2.30 \\
\hline Nerve growth factor ( $\beta$-polypeptide) & NGF & 281350 & Bt.12757.1.S1 & -2.41 \\
\hline ADP-ribosylation factor-like 15 & ISL1 & 614040 & Bt.28168.1.A1 & -2.54 \\
\hline Galanin prepropeptide & $G A L$ & 280799 & Bt.176.1.S1 & -2.56 \\
\hline Neurotrimin & NTM & 534414 & Bt.24379.1.A1 & -2.62 \\
\hline Hypothesized transcript & EMR3 & 526347 & Bt.21220.1.S1 & -2.63 \\
\hline Caveolin 1, caveolae protein, $22 \mathrm{kDa}$ & CAV1 & 281040 & Bt.2230.1.S1 & -2.64 \\
\hline $\begin{array}{l}\text { Potassium voltage-gated channel, } \\
\text { Shab-related subfamily, member } 2\end{array}$ & KCNB2 & 535990 & Bt.26994.1.A1 & -2.66 \\
\hline Purkinje cell protein 4 like 1 & PCP4L1 & 100126444 & Bt.5420.1.A1 & -2.81 \\
\hline Chemokine $(\mathrm{C}-\mathrm{X}-\mathrm{C}$ motif) ligand 2 & CXCL2 & 281212 & Bt.611.1.S2 & -2.90 \\
\hline Neuropeptide VF precursor & NPVF & 281451 & Bt.7042.1.S1 & -2.94 \\
\hline Matrix metallopeptidase 9 (gelatinase B) & MMP9 & 282871 & Bt.4714.1.S1 & -3.22 \\
\hline
\end{tabular}

${ }^{a}$ Averaged from values obtained using three normalization methods where $P$ value $<0.01$ and differences in relative abundance were at least twofold.

differentially abundant transcripts were subjected to the Kyoto Encyclopedia of Genes and Genomes (KEGG) biological pathway analysis (Kanehisa et al. 2006).

Other data were analyzed as a randomized block design with fixed effects of maturation temperature and hours of IVM when appropriate, blocking on replicate (i.e. day of oocyte collection), using binomial or normal distributions as appropriate and generalized linear mixed models (PROC GLIMMIX; SAS 9.2, SAS Inst., Inc., Cary, NC, USA). Treatment differences were determined using protected least significant differences and reported as least squares means \pm S.E.M. using the inverse link option. Regression of MMP9 levels explaining the development of blastocysts was assessed after blocking on replicate, and R-square was calculated from likelihoods (PROC GLIMMIX) as proposed by Nagelkerke (1991).

\section{Results}

\section{Transcriptome profiles of the cumulus surrounding the control and heat-stressed oocytes}

The comparison of the cumulus-derived transcriptome profiles after IVM of intact cumulus-oocyte complexes at 38.5 or $41{ }^{\circ} \mathrm{C}$ (heat stress during the first $12 \mathrm{~h}$ only and then shifted back to $38.5^{\circ} \mathrm{C}$ for a total of $24 \mathrm{~h}$; experimental schematic shown in Fig. 1) revealed a number of transcripts whose levels were increased $(n=11)$ or decreased $(n=13$; see Table 2$)$ by at least twofold after heat stress exposure $(P<0.01)$. Of the 24 transcripts, 23 were annotated. GO enrichment analysis was used to examine which molecular functions, biological processes, or cellular components may differ in the cumulus originating from the control and heatstressed cumulus-oocyte complexes (Table 3). Only one molecular function was overrepresented from the list of differentially expressed transcripts, whereas several biological processes and cellular components were found to be enriched. Biological pathway analysis (KEGG) suggested a possible overrepresentation of the Hedgehog signaling pathway in the cumulus surrounding the heatstressed oocytes (IHH and WNT2B were two significant transcripts of the 20 annotated ones; $P=0.002$ ).

Changes occurring at the transcriptome level in the cumulus surrounding the oocytes while heat stressed during maturation were coincident with a $46.4 \%$ reduction in the development of blastocysts $(27.4 \mathrm{vs}$ $15.7 \%$; S.E.M. $=1.8 \% ; P=0.004$ for the control and heat-stressed oocytes respectively) in the subsets of cumulus-oocyte complexes undergoing IVF. 
Table 3 Top gene ontology terms identified as overrepresented in cumulus derived from the cumulus-oocyte complexes matured after $24 \mathrm{~h}$ at $38.5 \mathrm{vs}$ $41.0^{\circ} \mathrm{C}$ (heat stress applied during the first $12 \mathrm{~h}$ only and then shifted back to $38.5^{\circ} \mathrm{C}$ ).

\begin{tabular}{|c|c|c|c|c|c|c|}
\hline \multirow{2}{*}{$\frac{\text { Accession no. }}{\text { Molecular functic }}$} & \multirow{2}{*}{ Terms } & \multirow[t]{2}{*}{$\begin{array}{c}\text { No. of genes } \\
\text { annotated }\end{array}$} & \multirow[t]{2}{*}{$\begin{array}{c}\text { No. of genes } \\
\text { expected }\end{array}$} & \multicolumn{2}{|c|}{ No. of genes significant ${ }^{a}$} & \multirow[t]{2}{*}{$P$ value $^{b}$} \\
\hline & & & & & & \\
\hline GO:0008083 & Growth factor activity & 74 & 0.15 & +2 & -0 & 0.009 \\
\hline \multicolumn{7}{|c|}{ Biological process } \\
\hline GO:0006952 & Defense response & 144 & 0.32 & +1 & -3 & 0.0002 \\
\hline GO:0006809 & Nitric oxide biosynthetic process & 21 & 0.05 & +1 & -1 & 0.001 \\
\hline GO:0007218 & Neuropeptide signaling pathway & 27 & 0.06 & +2 & -0 & 0.002 \\
\hline GO:0001666 & Response to hypoxia & 28 & 0.06 & +1 & -1 & 0.002 \\
\hline GO:0045596 & Negative regulation of cell differentiation & 52 & 0.12 & +1 & -1 & 0.006 \\
\hline GO:0048856 & Anatomical structure development & 724 & 1.62 & +4 & -2 & 0.003 \\
\hline GO:0030001 & Metal ion transport & 165 & 0.37 & +2 & -0 & 0.051 \\
\hline GO:0002376 & Immune system process & 345 & 0.77 & +1 & -2 & 0.038 \\
\hline GO:0045597 & Positive regulation of cell differentiation & 56 & 0.13 & +1 & -1 & 0.007 \\
\hline GO:0006807 & Nitrogen compound metabolic process & 196 & 0.44 & +1 & -2 & 0.008 \\
\hline \multicolumn{7}{|c|}{ Cellular component } \\
\hline GO:0031225 & Anchored to membrane & 30 & 0.07 & +1 & -1 & 0.002 \\
\hline GO:0048471 & Perinuclear region of cytoplasm & 37 & 0.09 & +1 & -1 & 0.003 \\
\hline GO:0005887 & Integral to plasma membrane & 75 & 0.18 & +2 & -0 & 0.013 \\
\hline GO:0005576 & Extracellular region & 611 & 1.46 & +5 & -2 & 0.0003 \\
\hline GO:0005578 & Proteinaceous extracellular matrix & 129 & 0.31 & +1 & -1 & 0.037 \\
\hline GO:0005615 & Extracellular space & 139 & 0.33 & +1 & -1 & 0.043 \\
\hline GO:0000139 & Golgi membrane & 151 & 0.36 & +1 & -1 & 0.049 \\
\hline GO:0005938 & Cell cortex & 52 & 0.12 & +1 & -1 & 0.007 \\
\hline
\end{tabular}

${ }^{a}$ Number of genes with a positive fold change $(+)$ and a negative fold change $(-)$; i.e. expression was increased or decreased in heat-stressed cumulus respectively. ${ }^{b}$ Based upon the number of significant genes vs the number expected of the total number of annotated bovine genes within each gene ontology term.

\section{Relative abundance of certain transcripts (CAV1, MMP9, FSHR, IHH, and NOS2) in the cumulus surrounding the control and heat-stressed oocytes using $q P C R$}

To determine the repeatability of some of the heatinduced changes detected using microarrays, the relative abundance of CAV1, MMP9, FSHR, IHH, and inducible NOS2 transcripts was examined in the cumulus originating from cumulus-oocyte complexes cultured at $38.5{ }^{\circ} \mathrm{C}$ for 0 (i.e. soon after the removal of follicles, but before placement into the IVM medium; nonmatured), 12, or $24 \mathrm{~h}$ IVM. Other subsets of intact cumulus-oocyte complexes were cultured at $41.0^{\circ} \mathrm{C}$ for $12 \mathrm{~h}$ IVM and removed for analysis or cultured for another $12 \mathrm{~h}$ after switching from 41 to $38.5^{\circ} \mathrm{C}$.

CAV1 and MMP9 transcripts were not detectable in cumulus RNA originating from the non-matured cumulus-oocyte complexes. Although similar at $12 \mathrm{~h}$ IVM, the relative abundance of CAV1 transcripts after $24 \mathrm{~h}$ IVM was 1.5-fold less in the cumulus originating from the heat-stressed oocytes ( $P=0.037$; Fig. 2A). Exposure to $41.0{ }^{\circ} \mathrm{C}$ reduced $M M P 9$ transcript levels by $\sim 2.5$-fold at 12 and $24 \mathrm{~h}$ IVM $(P<0.0001$; Fig. 2B). Primer sets targeting both the $3^{\prime}$ (Fig. 2C, D, and E) and $5^{\prime}$ (Fig. 2, inset panels $\mathrm{C}, \mathrm{D}$, and $\mathrm{E}$ ) regions of the $F S H R, I H H$, and NOS2 genes were derived for evaluating the relative abundance of the full-length mRNA. Relative quantities of these transcripts were highest at the onset of maturation (Fig. 2C, D, and E). While heat stress exposure had no effect on the relative abundance of FSHR transcripts at $12 \mathrm{~h}$ IVM, relative abundance after
24 h IVM was approximately twofold higher in the cumulus originating from the heat-stressed oocytes $(P=0.005 ;$ Fig. 2C). In contrast, heat-related differences in the abundance of $I H H$ transcripts were only detected at $12 \mathrm{~h}$ IVM (Fig. 2D). The abundance of NOS2 transcripts was higher in the cumulus originating from the heat-stressed oocytes at 12 and 24 h IVM (Fig. 2E).

The aforementioned changes occurring at the transcript level in the cumulus surrounding the oocytes while heat stressed during maturation were coincident with a $30.9 \%$ reduction in the development of blastocysts $(30.7$ vs $21.2 \%$; S.E.M. $=2.1 \% ; P=0.01$ for the control and heat-stressed oocytes respectively) in the subsets of cumulus-oocyte complexes undergoing IVF.

\section{Production of MMPs (MMP9 and MMP2) by the control and heat-stressed cumulus-oocyte complexes}

Because higher MMP9 levels have been associated with the developmental competence of oocytes (Robert et al. 2001), implantation and pregnancy rates (Lee et al. 2005, Horka et al. 2012), and fertility (Dubois et al. 2000), their abundance in the conditioned maturation medium (generated as a part of the transcriptome profiling efforts depicted in Fig. 1) observed after $24 \mathrm{~h} \mathrm{IVM}$ in the control and heatstressed oocytes was examined. Heat stress exposure during the first $12 \mathrm{~h}$ of maturation resulted in a 1.8-fold decrease in the levels of latent MMP9 at $24 \mathrm{~h}$ IVM ( $105 \mathrm{kDa}$; proMMP9); active MMP2 ( $65 \mathrm{kDa}$; MMP2) was not affected (Fig. 3). 
A

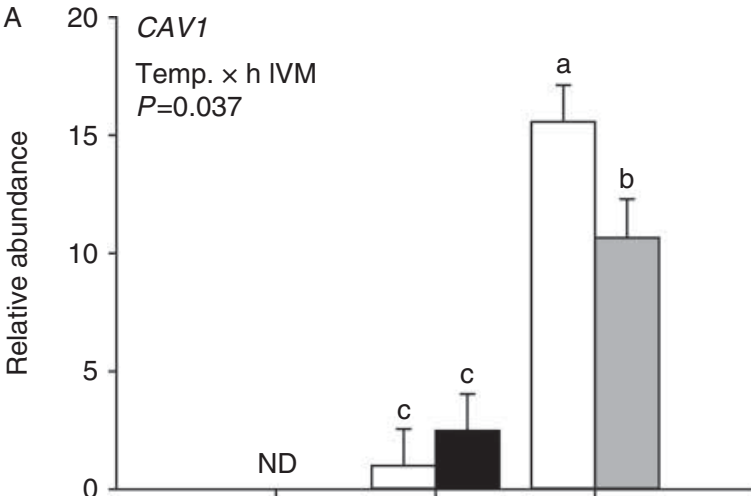

C

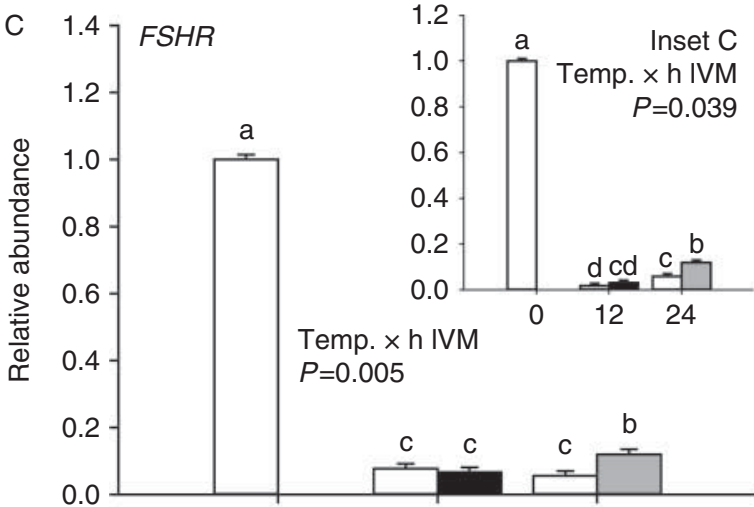

E

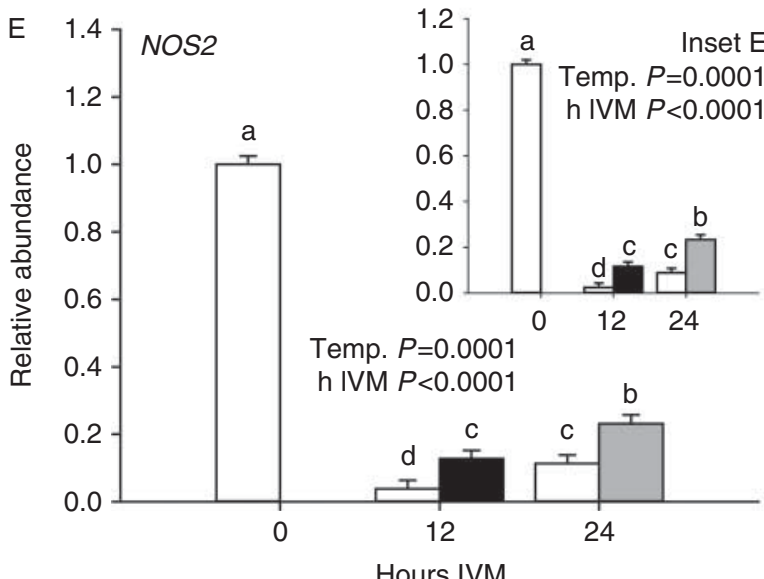

B
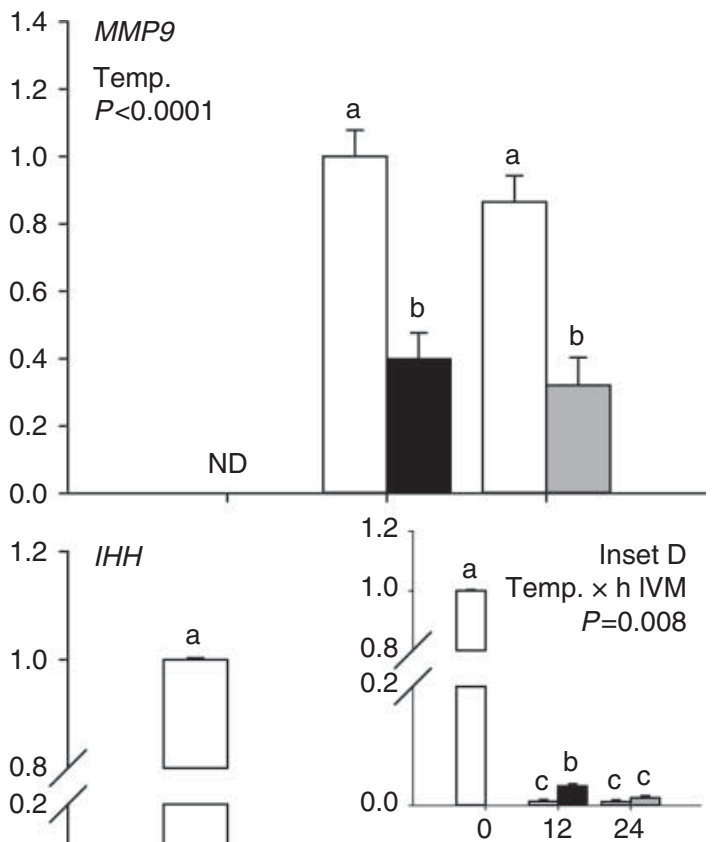

Temp. $\times$ h IVM

$P=0.007$

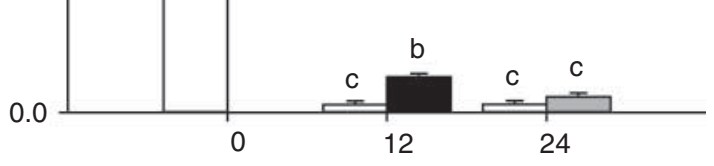

Hours IVM

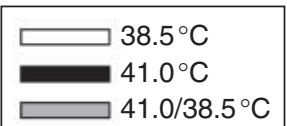

Figure 2 Relative abundance of the caveolin 1 (CAV1), matrix metallopeptidase 9 (MMP9), FSH receptor (FSHR), Indian hedgehog homolog (IHH), and inducible nitric oxide synthase (NOS2) transcripts in the cumulus surrounding the control and heat-stressed oocytes using qPCR. Transcripts were examined in cumulus originating from the cumulus-oocyte complexes cultured at $38.5^{\circ} \mathrm{C}$ for 0 (i.e. soon after the removal of follicles, but before placement into the IVM medium; non-matured), 12 , or $24 \mathrm{~h} \mathrm{IVM}$. Other subsets of intact cumulus-oocyte complexes were cultured at $41.0^{\circ} \mathrm{C}$ for $12 \mathrm{~h}$ IVM and removed for analysis or cultured for another $12 \mathrm{~h}$ after switching from 41.0 to $38.5^{\circ} \mathrm{C}\left(41.0 / 38.5^{\circ} \mathrm{C}\right)$. The relative abundance of CAV1 (A) and MMP9 (B) mRNAs were determined after calibration to 12-h IVM and $38.5^{\circ} \mathrm{C}$ cumulus sample as neither were detectable (ND) at 0 $\mathrm{h}$ IVM. Calibrator sample for calculating the relative abundance of $F S H R(\mathrm{C}), I H H(\mathrm{D})$ and $N O S 2$ (E) transcripts was the 0-h IVM cumulus sample. The insets in panels $\mathrm{C}, \mathrm{D}$, and $\mathrm{E}$ depict data utilizing primers for the $3^{\prime}$ end of the $F S H R, I H H$, and NOS2 genes respectively. Bars (least squares means \pm S.E.M.) with different letters denote significance for the main effects of maturation temperature (Temp.) and/or time (h IVM) or interaction of maturation temperature and time (Temp. $\times$ h IVM).

The repeatability of the aforementioned findings was confirmed in a separate additional study using the conditioned maturation medium obtained after the maturation of the intact control and heat-stressed cumulus-oocyte complexes for $24 \mathrm{~h}$. To this end, heat stress exposure during the first $12 \mathrm{~h}$ only resulted in a 1.7-fold reduction in proMMP9 levels (331 vs 194 densitometric units per cumulus-oocyte complex matured at 38.5 and $41.0^{\circ} \mathrm{C}$ respectively, s.E.M. $=29$; $P=0.0008$ ) without any effect on MMP2 levels (231 vs 256 densitometric units per cumulus-oocyte complex matured at 38.5 and $41.0{ }^{\circ} \mathrm{C}$ respectively, S.E.M. $=24$; 

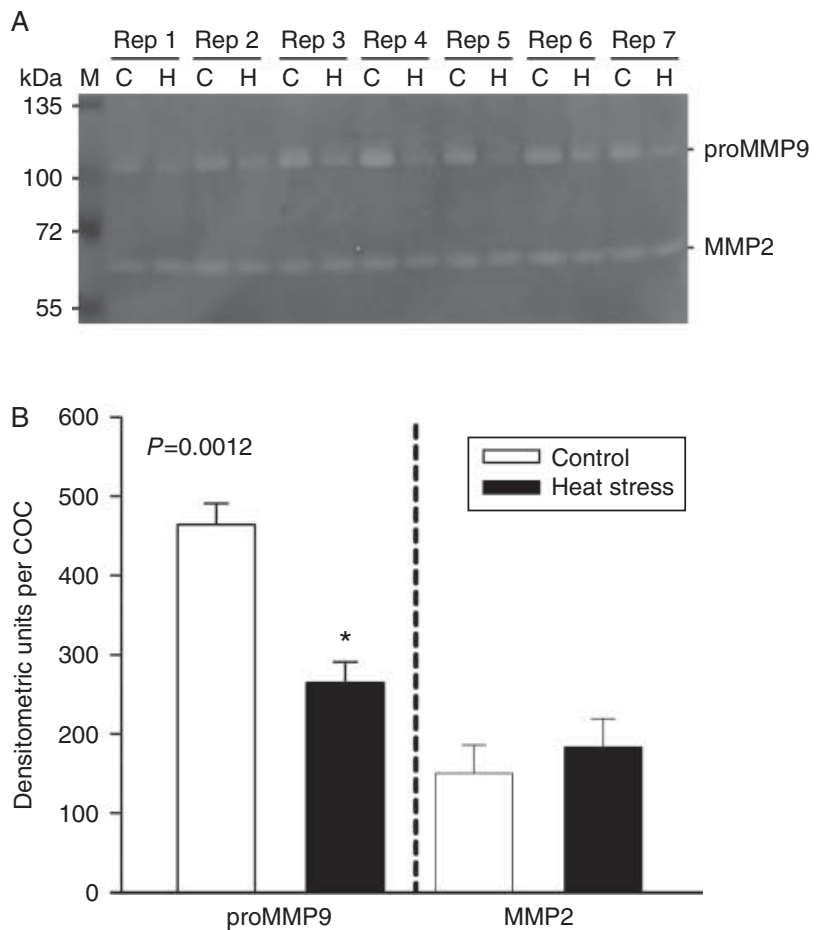

Figure 3 Heat-induced decreases in matrix metallopeptidase (MMP) levels in the conditioned medium collected after the maturation of cumulus-oocyte complexes for $24 \mathrm{~h}$ IVM as depicted in Fig. 1. (A) Gelatin zymogram of representative samples: $\mathrm{C}$ - control $\left(38.5^{\circ} \mathrm{C}\right)$; $\mathrm{H}$ - heat stress $\left(41.0^{\circ} \mathrm{C}\right.$ for the first $12 \mathrm{~h}$ IVM and then shifted back to $38.5^{\circ} \mathrm{C}$ ); $\mathrm{M}$ - marker, relative molecular weight standards; proMMP9 - latent form of MMP9; and MMP2 - the active form of MMP2. (B) Comparison of the band intensities of proMMP9 and the active form of MMP2 after adjusting for the number of cumulus-oocyte complexes (COCs) per well. *Bars (least squares means \pm s.E.M.) statistically different within a MMP comparison.

$P=0.0008)$ without any effect on MMP2 levels (231 vs 256 densitometric units per cumulus-oocyte complex matured at 38.5 and $41.0^{\circ} \mathrm{C}$ respectively, S.E.M. $=24$; $P=0.217)$. In this experimental effort, heat-induced reductions in proMMP9 levels were coincident with a $19.4 \%$ reduction in the development of blastocysts (26.3 vs $21.2 \%$ for the control and heat-stressed groups respectively; S.E.M. $=1.7 \% ; P<0.03$ ) in the subsets of cumulus-oocyte complexes undergoing IVF.

Data from transcriptome profiling effort and the additional study conducted to examine the repeatability of heat-induced reductions in proMMP9 levels were combined to examine the relationship of proMMP9 levels in the maturation medium at $24 \mathrm{~h}$ IVM with the development rate of blastocysts after oocytes enveloped in the affected cumulus underwent IVF. In this dataset, the development rate of blastocysts ranged from 7 to $45 \%$. Independent of maturation temperature, the development of blastocysts was positively associated with proMMP9 levels in the conditioned maturation medium at $24 \mathrm{~h}$ IVM (Fig. $4 ; R^{2}=0.36 ; P=0.002$ ).
The initial identities of MMP9 and MMP2 were determined by comparison with the molecular weight standards in the adjacent lane (molecular weight macro; Image)). Bands were confirmed to be those of gelatinases as the presence of $20 \mathrm{mM}$ EDTA during zymogram development eliminated the digestion of gelatin (data not shown). Subsequent confirmation of band identities was done by comparing the conditioned maturation medium with recombinant human standards of proMMP9 and proMMP2 in the absence or presence of gelatinase activator, APMA. Treatment of the conditioned maturation medium with APMA resulted in a $105 \mathrm{kDa}$ band, identified as that of proMMP9, being activated to an $\sim 87 \mathrm{kDa}$ form without a similar alteration being observed for the $65 \mathrm{kDa}$ band identified as that belonging to MMP2 (Fig. 5). Low-molecular-weight forms observed for recombinant standards and unconditioned maturation medium were probably due to the absence of tissue inhibitors of metallopeptidases (Fig. 5; Toth \& Fridman 2001). The majority of MMP2 may have originated from fetal bovine serum in the maturation medium, as its presence was detected in the non-conditioned supplemented medium (Fig. 5), yet it was absent in the M199 base medium (data not shown).

\section{Production of MMPs (MMP9 and MMP2) and progesterone during IVM of cumulus-oocyte complexes at 38.5 or $41.0^{\circ} \mathrm{C}$}

MMP9 transcripts were not detected in the non-matured cumulus-oocyte complexes (Fig. 6). Although heatinduced reductions in transcript levels were first observed at $6 \mathrm{~h}$ IVM $(P<0.0001$; Fig. 6A), reductions in protein levels (proMMP9) were not observed until

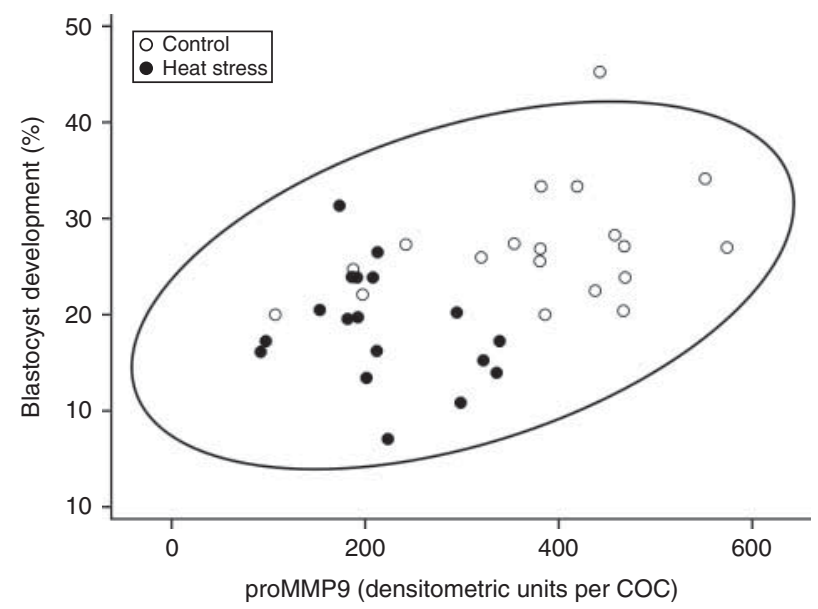

Figure 4 Percentage blastocyst development after the fertilization of control (open circles) and heat-stressed (filled circles) cumulus-oocyte complexes plotted against the levels of latent matrix metalloproteinase 9 (proMMP9) in the conditioned maturation medium after $24 \mathrm{~h} \mathrm{IVM.}$ Control oocytes were cultured at $38.5^{\circ} \mathrm{C}$, whereas those experiencing heat stress were cultured at $41.0^{\circ} \mathrm{C}$ for the first $12 \mathrm{~h}$ IVM and then shifted to $38.5^{\circ} \mathrm{C}$. 


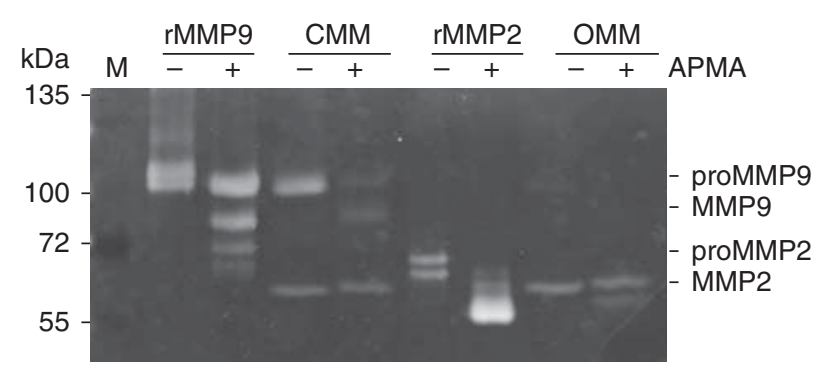

Figure 5 Gelatin zymogram loaded with recombinant matrix metallopeptidase 9 (latent form, proMMP9), conditioned maturation medium (CMM), recombinant proMMP2, and non-conditioned maturation medium (OMM) without $(-)$ and with $(+)$ p-aminophenylmercuric acetate (APMA) pretreatment. The latent forms of metallopeptidases (105 kDa for proMMP9 and $72 \mathrm{kDa}$ for proMMP2) cleave into not only active forms (87 kDa for proMMP9 and $62 \mathrm{kDa}$ for proMMP2) but also intermediate forms (68 kDa for MMP2) and low-molecular-mass forms ( 77 and $71 \mathrm{kDa}$ for MMP9 and $56 \mathrm{kDa}$ for MMP2) probably due to the absence of tissue inhibitors of metallopeptidases (Toth \& Fridman 2001). M - marker lane of relative molecular weight standards used to estimate the size of bands.

18 h IVM ( $P=0.0002$; Fig. 6C). MMP2 transcripts were not detected at any of the time points examined (Fig. 6B); protein levels remained constant throughout maturation and were not affected by heat stress exposure (Fig. 6D). The production of progesterone increased during IVM $(P=0.024)$; heat-induced increases were evident at 12 h IVM ( $P=0.002$; Fig. 7$)$. Results showing heat-induced increases in the production of progesterone were obtained again on using the conditioned maturation medium originating from the microarray study. The amounts of progesterone produced per each control and heat-stressed cumulus-oocyte complex were 529 and $636 \mathrm{pg}$ respectively $(P=0.0015 ;$ S.E.M. $=36)$. Progesterone was not detected in the non-conditioned maturation medium.

\section{Discussion}

In an effort to identify processes perturbed in the cumulus enveloping the maturing oocyte during heat stress, biological themes were extracted from a list of differentially expressed transcripts by functional annotation in conjunction with GO and pathway analyses. Although a number of functions were determined to be overrepresented, a few of the GO terms were represented by more than two genes. As a consequence, focus was placed on individual transcripts found to be differentially expressed.

To this end, findings described herein provide novel insights into the molecular and cellular mechanism(s) whereby heat stress exposure during maturation directly affects the intimately associated cumulus cells that envelop the maturing oocyte. Heat-induced reductions in the development of blastocysts after
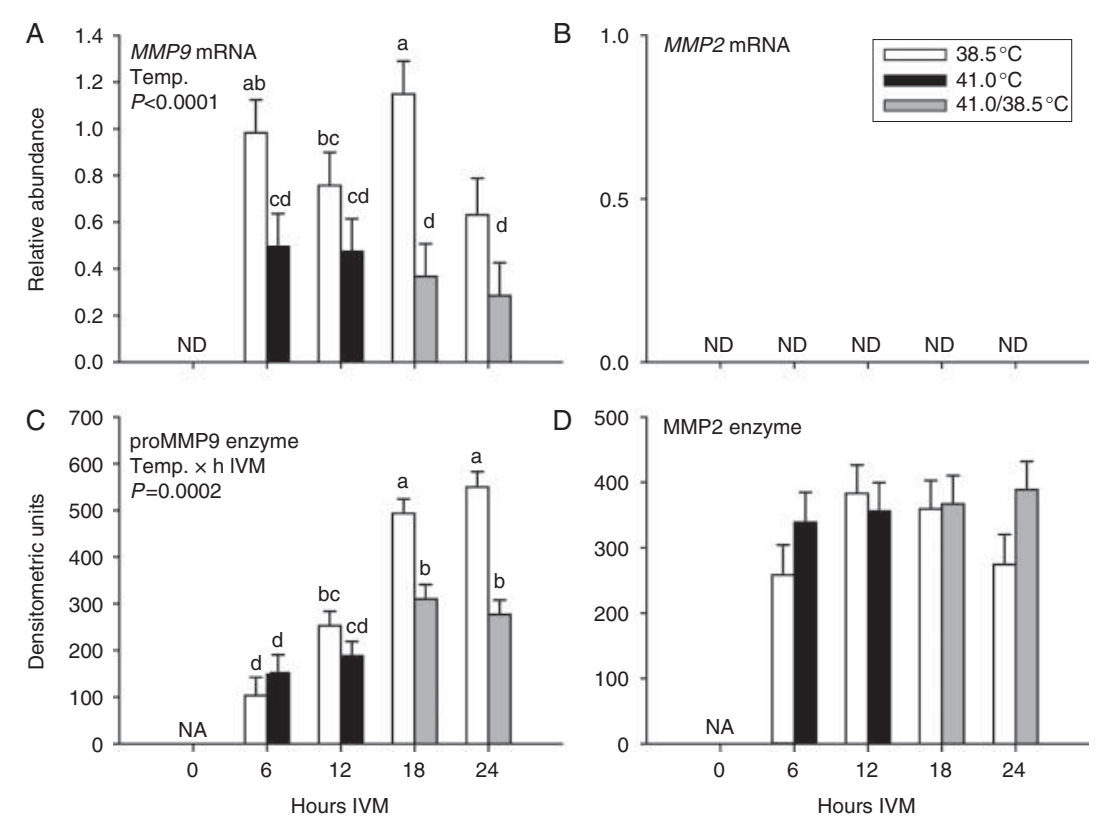

Figure 6 Production of matrix metallopeptidases (MMP9 and MMP2) during IVM of cumulus-oocyte complexes at 38.5 or $41.0^{\circ} \mathrm{C}$. Cumulus-oocyte complexes underwent IVM for $24 \mathrm{~h}$ at $38.5^{\circ} \mathrm{C}$ (control) or $41.0^{\circ} \mathrm{C}$ (heat stress applied during the first $12 \mathrm{~h}$ only and then shifted back to $38.5^{\circ} \mathrm{C}$ ). Subsets were removed from culture at $0,6,12,18$, and $24 \mathrm{~h} \mathrm{IVM}$. The associated conditioned maturation medium was collected and maintained separately based on treatment and $\mathrm{h}$ IVM. (A) Relative abundance of MMP9 mRNA as determined by qPCR; samples were calibrated to the 6-h and $38.5^{\circ} \mathrm{C}$ COC sample as mRNA for MMP9 was not detectable (ND) at $0 \mathrm{~h}$ IVM. Bars (least squares means \pm s.E.M.) with different letters denote significance for the main effect of maturation temperature (Temp.). (B) Presence of MMP2 transcripts in total RNA was not detectable (ND) by qPCR at any time or IVM temperature. (C) Levels of proMMP9 enzyme in the conditioned medium per gelatin zymography at $6,12,18$, and $24 \mathrm{~h}$ of maturation. Bars with different letters denote a significant IVM temperature $\mathrm{x}$ hours of maturation interaction (Temp. $\times \mathrm{h}$ IVM). (D) Levels of MMP2 enzyme in the CMM were similar regardless of the increased time or temperature of maturation. NA, not applicable. 


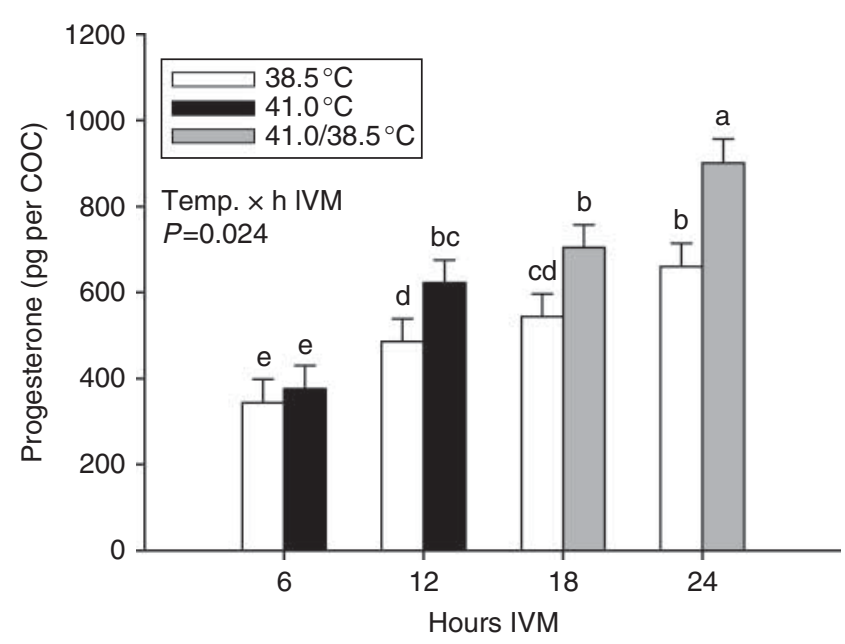

Figure 7 Progesterone production during IVM of cumulus-oocyte complexes at 38.5 or $41.0^{\circ} \mathrm{C}$. Cumulus-oocyte complexes underwent IVM for $24 \mathrm{~h}$ at $38.5^{\circ} \mathrm{C}$ (control) or $41.0^{\circ} \mathrm{C}$ (heat stress applied up to the first $12 \mathrm{~h}$ only and then shifted back to $38.5^{\circ} \mathrm{C}$ ). The conditioned maturation medium was collected and maintained separately based on treatment and h IVM. Bars (least squares means \pm s.E.M.) with different letters denote a significant IVM temperature $\mathrm{x}$ h IVM interaction.

fertilization were coincident with changes in the relative abundance of several developmentally important cumulus-derived transcripts. Validation experiments confirmed heat-induced reductions in the MMP9 transcript and protein levels. Heat-induced increases in the production of progesterone attest to the notion that the cumulus cells originating from the heat-stressed oocytes are functionally different from their non-heat-stressed counterparts. Because of the importance of these two cumulus-derived components (Regassa et al. 2011) in the developmental competence of the oocyte (Dubois et al. 2000, Silva \& Knight 2000, Robert et al. 2001, Yamashita et al. 2003, Lee et al. 2005, Aparicio et al. 2011), collectively these findings support the notion for some of the negative consequences of heat stress on the cumulus-oocyte complex are mediated through the cumulus.

During IVM, MMP9 is expressed exclusively by the cumulus surrounding the oocyte (Regassa et al. 2011). Our study shows a strong relationship between proMMP9 levels and embryo development occurring after fertilization of the cumulus-oocyte complexes. Thus, heat-induced reductions in MMP9 levels may provide a plausible mechanism to explain why some of the hyperthermia-related reductions in the developmental competence of maturing oocytes occur. This transcript has been identified previously as a marker of bovine oocyte competence because its presence was only detected in the granulosa of follicles yielding oocytes competent to undergo development into embryos after fertilization (Robert et al. 2001). Lee et al. (2005) concluded that high levels of proMMP9 in preovulatory follicular fluid were requisite for successful implantation and pregnancy in human IVF. The absence of MMP9 is detrimental to fertility as deficient mice have smaller litter sizes and increased percentages of infertile breeding pairs (Dubois et al. 2000).

MMP9 is secreted as a $92 \mathrm{kDa}$ glycosylated prometalloenzyme, which transforms from a latent (proMMP9) to an active form through a cascade of proteolytic steps involving other MMPs (e.g. MMP2, MMP3, MMP7, and MMP13), urokinase type (uPA), and tissue type plasminogen activators (tPA; reviewed by Van den Steen et al. (2002)). Active MMP9 may cleave various substrates (e.g. myelin basic protein, growth factors, interleukins, interleukin receptors, and protease inhibitors; reviewed by Van den Steen et al. (2002)). Interaction with the tissue inhibitors of matrix metallopeptidase 1 (TIMP1) regulates activity (reviewed by Van den Steen et al. (2002)). Using different approaches (i.e. microarray, qPCR, and zymography) on numerous different occasions with different batches of oocytes, it was found that heat stress consistently reduced transcript (2.2-fold (qPCR) to 3.2-fold (microarray)) and proMMP9 (1.7- to 2 -fold) levels. Inability to detect the active MMP9 enzyme may be due to a short half-life (Demestre et al. 2005). This does not preclude a functional role for proMMP9 as active MMP9 has rarely been observed in conditioned media even when activity is evident (Fridman et al. 2003). Heat stress exposure reduced the transcript levels of PLAU, MMP1, and MMP19 by 1.7-, $1.6-$, and 1.8-fold respectively; the abundance of MMP23B, PLAT, TIMP1, and TIMP2 transcripts was not altered (data not shown). Cumulus RNA did not have detectable levels of MMP2 transcripts, which is consistent with a study reporting presence in theca cells only (Liu et al. 1998).

The lack of available studies documenting the importance of MMPs during oocyte maturation poses a challenge for explaining the biological significance of heat-induced reductions in proMMP9 levels. In other cell types, MMPs regulate the bioavailability of various growth factors and cytokines (reviewed by Sternlicht \& Werb (2001)). The active form of MMP9 in keratinocytes associates with hyaluronan-CD44 (hyaluronic acid receptor) at the cell surface, cleaving transforming growth factor- $\beta$ into an active form (Yu \& Stamenkovic 2000), which influences meiotic maturation in porcine (Coskun \& Lin 1994) and murine (Feng et al. 1988, Tsafriri et al. 1989) oocytes. Notably, each of these components is present in the bovine cumulus-oocyte complex (this study, Furnus et al. 2003, Gilchrist et al. 2003, Schoenfelder \& Einspanier 2003, Regassa et al. 2011). Depending on the extent to which function is similar in other cell types, heat-induced reductions in cumulusderived MMP9 levels may alter the balance of factors favoring stimulatory ligands for meiotic maturation.

While functional significance remains speculative, lower than expected MMP9 levels observed at $24 \mathrm{~h}$ IVM may be a consequence of heat-induced increases in cumulus-derived progesterone production. In two 
different studies utilizing cumulus-oocyte complexes collected on numerous occasions, heat stress exposure increased the production of progesterone. Microarray data showed concomitant heat-induced increases in the cumulus-derived transcripts of CYP11A1 (1.6-fold change in the cytochrome $\mathrm{P} 450$ side-chain cleavage enzyme responsible for the conversion of cholesterol into pregnenolone; Payne \& Hales (2004)) and HSD3B1 (1.8-fold change in $3 \beta$-hydroxysteroid dehydrogenase, which catalyzes the conversion of pregnenolone into progesterone; Payne \& Hales (2004)). Others have shown that progesterone suppresses the secretion of MMP9 in cultured cervical fibroblasts (Imada et al. 1997) and firsttrimester placental cells (Shimonovitz et al. 1998). Using human endometrial explants, Marbaix et al. (1992) showed that physiological concentrations of progesterone almost completely abolished the secretion of MMP9.

Cumulus cells secrete less estradiol and more progesterone during oocyte maturation (Schoenfelder et al. 2003, Tosca et al. 2007). Changes in functionality are probably attributable to a reversion to a mural granulosa cell state (Chaffin et al. 2012). In this context, heat-induced increases in cumulus-derived progesterone, while a novel finding of our study, are consistent with data reported by Wolfenson et al. (1997) showing an increased production of progesterone by granulosa cells originating from the follicles of heatstressed cows. Hyperthermia-related consequences were probably due to the direct effects of elevated temperatures as Bridges et al. (2005) showed that the cumulative secretion of progesterone by follicle wall pieces in a medium alone was higher when cultured at $41.0^{\circ} \mathrm{C}$ than at 39 or $37^{\circ} \mathrm{C}$.

Exposure to higher-than-'expected' progesterone levels from the surrounding cumulus during heat stress may not be without a negative consequence on subsequent embryo development. In porcine oocytes, a higher level of progesterone production by cumulus cells accelerated the breakdown of germinal vesicles (Yamashita et al. 2003). Furthermore, increasing amounts of progesterone in the maturation medium enhanced the meiotic progression of bovine oocytes (Sirotkin 1992). Although the effects of progesterone levels observed after heat stress exposure on meiotic maturation were not determined in this study, findings in two different species document the effects of heat stress exposure during maturation on hastening developmentally important processes. For instance, Baumgartner \& Chrisman (1981) reported a higher percentage of murine oocytes having a bicellular classification (i.e. oocytes contained two cells, with one presumed to be the first polar body) after in vivo heat stress exposure. This is consistent with results reported by Kim et al. (2002) suggesting that a short-term heat shock permissive of meiotic maturation in murine oocytes accelerated the breakdown of germinal vesicles. After direct application of heat stress the same as that used in our study, Edwards et al. (2005) demonstrated that more bovine oocytes progressed to metaphase I by $8 \mathrm{~h}$ IVM, metaphase II by $18 \mathrm{~h}$ IVM, and completed cortical granule translocation to the oolemma by $24 \mathrm{~h}$ IVM compared with those not exposed to heat stress. Rispoli et al. (2011) showed that heat-stressed oocytes similar to older MII oocytes were activated more readily than younger MII oocytes. Schrock et al. (2007) demonstrated that earlier fertilization improved the developmental competence of heat-stressed oocytes.

Siqueira et al. (2012) showed that progesterone induces meiotic maturation in bovine species in a dose-dependent manner. When cultured with follicular hemisections, progression to MII was enhanced using progesterone concentrations $\leq 100 \mathrm{ng}$; at concentrations $\geq 1000 \mathrm{ng}$, meiotic progression was less than optimal. Depending on the extent to which heat-induced increases in the production of progesterone affect meiotic progression, it would be interesting to evaluate progesterone levels in instances where the consequences of heat stress are severe enough to inhibit meiotic progression (Roth \& Hansen 2005, MayaSoriano et al. 2012, Nabenishi et al. 2012).

In two different studies reported herein, the relative abundance of the transcripts of NOS2 (the inducible form of nitric oxide synthase) was higher in cumulus originating from the heat-stressed oocytes at $24 \mathrm{~h} \mathrm{IVM}$ (2.3-fold (qPCR) to 2.7-fold (microarray)). The results reported by Matta et al. (2009) showing that the inhibition of NOS2 during oocyte maturation reduced cumulus expansion, meiotic progression after germinal vesicle breakdown, cortical granule migration, and embryo development after IVF warrant further investigation. Depending on the extent to which transcript levels correspond to the presence of functional protein, it is plausible for heat-induced increases to explain some of the heat-induced hastening of meiotic maturation noted previously.

The Hedgehog signaling pathway has previously been shown to play a role in the development of thecae and the expansion of cumuli in mice (Wijgerde et al. 2005, Ren et al. 2009). The Indian Hedgehog ligand after binding to the Patched receptor stimulates intracellular signaling to alter the transcription of downstream targets including the WNT family members (reviewed by Cohen (2003)). The abundance of $I H H$ transcripts decreased during oocyte maturation (this study, Hernandez-Gonzalez et al. 2006, Ren et al. 2009, Regassa et al. 2011). Cumulus originating from the heat-stressed oocytes had higher amounts after $12 \mathrm{~h}$ IVM (4.7-fold, qPCR) or $24 \mathrm{~h}$ IVM (2.7fold, microarray). Because heat stress exposure also resulted in a threefold increase in $W N T 2 B$ transcript levels, it is plausible for heat-induced differences to be meaningful. In murine oocytes, elevated Hedgehog signaling resulted in a disorganized expansion of cumulus (Ren et al. 2009). 
The effects of heat stress exposure on cumulus-oocyte complexes are dependent on severity and duration (Edwards \& Hansen 1996, Payton et al. 2004). Prolonged heat stress exposure reduces the expansion of cumulus by reducing the production of hyaluronic acid (Lenz et al. 1983). In the context of our model, however, the expansion of cumulus after exposure during the first $12 \mathrm{~h}$ IVM is more often than not indistinguishable in heat-stressed vs non-heat-stressed controls at $24 \mathrm{~h}$ IVM. The expansion of cumulus is mediated, in large part, by FSH (Eppig 1979a, 1979b). The use of microarray and qPCR showed that while FSHR transcript levels were decreased (2.5-fold and 2.1-fold respectively) during maturation (this study, Nuttinck et al. 2004, Hernandez-Gonzalez et al. 2006, Regassa et al. 2011, Salhab et al. 2011), cumulus originating from the heat-stressed oocytes had higher amounts at $24 \mathrm{~h} \mathrm{IVM}$.

Caveolin 1, a scaffolding protein of lipid raft domains on the plasma membrane, has been shown to regulate signal transduction (Ceresa \& Schmid 2000) and to co-immunoprecipitate with FSHR (McKenize \& Cohen 2009). Heat-induced reductions in the abundance of CAV1 transcripts (1.7-fold (qPCR) to 2.6-fold (microarray)) may be indicative of impaired signal transduction of FSHR. Although interesting, inferences related to the significance of these and other transcriptbased findings are limited, as Nuttinck et al. (2004) reported that changes in FSHR transcript levels during maturation are not always accompanied by changes in protein levels.

Nonetheless, heat-induced perturbations evident in the cumulus cells that envelop the maturing oocyte involving different biological processes, cellular components, and molecular functions are intriguing as the presence of cumulus is required for the acquisition of developmental competence. Because cumulus cells are transcriptionally active, it was not surprising that heat stress exposure invoked a defense response (CXCL2, VNN1, NOS2, and ORM1) similar to that which occurs in response to an injury. Hypoxia-related responses (CAV1 and NOS2) have been shown to activate the heat shock response in other cell types (Benjamin et al. 1990). Cumulus cells are no exception, as Payton et al. (2011) have previously shown that heat stress exposure similar to that utilized in our study elicited a heat shock response. In the context of the studies described, herein heat stress exposure affected growth factor activity (CXCL2 and NGF). When coupled with changes in transcript levels associated with the extracellular region (MMP9, NPVF, CXCL2, GAL, NGF, FMOD, and ORM), these findings are suggestive of heat-induced alterations in the paracrine signaling microenvironment enveloping the maturing oocyte. Depending on the extent to which this occurs, it is certainly plausible for consequences to possibly affect the maturing oocyte enveloped within.

\section{Declaration of interest}

The authors declare that there is no conflict of interest that could be perceived as prejudicing the impartiality of the research reported.

\section{Funding}

This research was supported in part by the National Research Initiative Competitive Grant (grant number 2004-3520314772) from the United States Department of Agriculture Cooperative State Research, Education, and Extension Service, United States Department of Agriculture Hatch Funds, the state of Tennessee through the University of Tennessee AgResearch, and the Department of Animal Science.

\section{Acknowledgements}

The authors thank Amanda Ward, T J Wilson, Gretchen Schrock, Nancy Rohrbach, Jessy Harris, and Matt Backus, whose assistance was essential for the completion of the project. Hybridization and scanning of microarrays were performed by the Vanderbilt Functional Genomics Shared Resource, which is supported in part by the Vanderbilt Ingram Cancer Center (P30 CA68485). They extend their appreciation to Vicky Amann for invaluable advice and assistance with the microarray study. They also extend their gratitude to Dr Neal Stewart (University of Tennessee, Knoxville) and Laura GoodAbercrombie (University of Tennessee, Knoxville) for providing the GFP plasmid.

\section{References}

Aparicio IM, Garcia-Herreros M, O'Shea LC, Hensey C, Lonergan P \& Fair T 2011 Expression, regulation, and function of progesterone receptors in bovine cumulus oocyte complexes during in vitro maturation. Biology of Reproduction 84 910-921. (doi:10.1095/ biolreprod.110.087411)

Baumgartner AP \& Chrisman CL 1981 Cytogenetic analysis of ovulated mouse oocytes following hyperthermic stress during meiotic maturation. Experimental Cell Research 132 359-366. (doi:10.1016/00144827(81)90111-7)

Benjamin IJ, Kröger B \& Williams RS 1990 Activation of the heat shock transcription factor by hypoxia in mammalian cells. PNAS $\mathbf{8 7}$ 6263-6267. (doi:10.1073/pnas.87.16.6263)

Bridges PJ, Brusie MA \& Fortune JE 2005 Elevated temperature (heat stress) in vitro reduces androstenedione and estradiol and increases progesterone secretion by follicular cells from bovine dominant follicles. Domestic Animal Endocrinology 29 508-522. (doi:10.1016/j.domaniend.2005.02.017)

Ceresa BP \& Schmid SL 2000 Regulation of signal transduction by endocytosis. Current Opinion in Cell Biology 12 204-210. (doi:10. 1016/S0955-0674(99)00077-0)

Chaffin CL, Lee YS, Vandevoort CA, Patel BG \& Latham KE 2012 Rhesus monkey cumulus cells revert to a mural granulosa cell state after an ovulatory stimulus. Endocrinology 153 5535-5545. (doi:10.1210/en. 2012-1733)

Cohen MM Jr 2003 The hedgehog signaling network. American Journal of Medical Genetics. Part A 123A 5-28. (doi:10.1002/ajmg.a.20495)

Coskun S \& Lin YC 1994 Effects of transforming growth factors and activin-A on in vitro porcine oocyte maturation. Molecular Reproduction and Development 38 153-159. (doi:10.1002/mrd.1080380206) 
Demestre M, Parkin-Smith G, Petzold A \& Pullen AH 2005 The pro and the active form of matrix metalloproteinase- 9 is increased in serum of patients with amyotrophic lateral sclerosis. Journal of Neuroimmunology 159 146-154. (doi:10.1016/j.jneuroim.2004.09.015)

Dubois B, Arnold B \& Opdenakker G 2000 Gelatinase B deficiency impairs reproduction. Journal of Clinical Investigation 106 627-628. (doi:10. 1172/JCI10910)

Edwards JL \& Hansen PJ 1996 Elevated temperature increases heat shock protein 70 synthesis in bovine two-cell embryos and compromises function of maturing oocytes. Biology of Reproduction 55 341-346. (doi:10.1095/biolreprod55.2.341)

Edwards JL \& Hansen PJ 1997 Differential responses of bovine oocytes and preimplantation embryos to heat shock. Molecular Reproduction and Development 46 138-145. (doi:10.1002/(SICl)1098-2795(199702)46:2 $<138:$ :AID-MRD4>3.0.CO;2-R)

Edwards JL, King WA, Kawarsky SJ \& Ealy AD 2001 Responsiveness of early embryos to environmental insults: potential protective roles of HSP70 and glutathione. Theriogenology 55 209-223. (doi:10.1016/S0093691X(00)00455-6)

Edwards JL, Saxton AM, Lawrence JL, Payton RR \& Dunlap JR 2005 Exposure to a physiologically relevant elevated temperature hastens in vitro maturation in bovine oocytes. Journal of Dairy Science $\mathbf{8 8}$ 4326-4333. (doi:10.3168/jds.S0022-0302(05)73119-2)

Edwards JL, Bogart AN, Rispoli LA, Saxton AM \& Schrick FN 2009 Developmental competence of bovine embryos from heat-stressed ova. Journal of Dairy Science 92 563-570. (doi:10.3168/jds.2008-1495)

Eppig JJ 1979a FSH stimulates hyaluronic acid synthesis by oocyte-cumulus cell complexes from mouse preovulatory follicles. Nature 281 483-484. (doi:10.1038/281483a0)

Eppig J 1979b Gonadotropin stimulation of the expansion of cumulus oophori isolated from mice: general conditions for expansion in vitro. Journal of Experimental Zoology 208 111-120. (doi:10.1002/jez. 1402080112)

Feng P, Catt KJ \& Knecht M 1988 Transforming growth factor- $\beta$ stimulates meiotic maturation of the rat oocyte. Endocrinology 122 181-186. (doi:10.1210/endo-122-1-181)

Fridman R, Toth M, Chvyrkova I, Meroueh SO \& Mobashery S 2003 Cell surface association of matrix metalloproteinase-9 (gelatinase B). Cancer and Metastasis Reviews 22 153-166. (doi:10.1023/A:1023091214123)

Furnus CC, Valcarcel A, Dulout FN \& Errecalde AL 2003 The hyaluronic acid receptor (CD44) is expressed in bovine oocytes and early stage embryos. Theriogenology 60 1633-1644. (doi:10.1016/S0093691X(03)00116-X)

Gentleman RC, Carey VJ, Bates DM, Bolstad B, Dettling M, Dudoit S, Ellis B, Gautier L, Ge Y, Gentry J et al. 2004 Bioconductor: open software development for computational biology and bioinformatics. Genome Biology 5 R80. (doi:10.1186/gb-2004-5-10-r80)

Geshi M, Takenouchi N, Yamauchi N \& Nagai T 2000 Effects of sodium pyruvate in nonserum maturation medium on maturation, fertilization, and subsequent development of bovine oocytes with or without cumulus cells. Biology of Reproduction 63 1730-1734. (doi:10.1095/biolreprod63.6.1730)

Gilchrist R, Morrissey M, Ritter L \& Armstrong D 2003 Comparison of oocyte factors and transforming growth factor- $\beta$ in the regulation of DNA synthesis in bovine granulosa cells. Molecular and Cellular Endocrinology 201 87-95. (doi:10.1016/S0303-7207(02)00429-X)

Hernandez-Gonzalez I, Gonzalez-Robayna I, Shimada M, Wayne CM, Ochsner SA, White L \& Richards JS 2006 Gene expression profiles of cumulus cell oocyte complexes during ovulation reveal cumulus cells express neuronal and immune-related genes: does this expand their role in the ovulation process? Molecular Endocrinology 20 1300-1321. (doi:10.1210/me.2005-0420)

Horka P, Malickova K, Jarosova R, Janatkova I, Zima T \& Kalousova M 2012 Matrix metalloproteinases in serum and the follicular fluid of women treated by in vitro fertilization. Journal of Assisted Reproduction and Genetics 29 1207-1212. (doi:10.1007/s10815-012-9853-4)

Huber W, von Heydebreck A, Sultmann H, Poustka A \& Vingron M 2002 Variance stabilization applied to microarray data calibration and to the quantification of differential expression. Bioinformatics 18 (Suppl 1) S96-S104. (doi:10.1093/bioinformatics/18.suppl_1.S96)
Hyttel P, Callesen H \& Greve T 1986a Ultrastructural features of preovulatory oocyte maturation in superovulated cattle. Journal of Reproduction and Fertility 76 645-656. (doi:10.1530/jrf.0.0760645)

Hyttel P, Xu KP, Smith S \& Greve T 1986b Ultrastructure of in-vitro oocyte maturation in cattle. Journal of Reproduction and Fertility 78 615-625. (doi:10.1530/jrf.0.0780615)

Imada K, Ito A, Sato T, Namiki M, Nagase H \& Mori Y 1997 Hormonal regulation of matrix metalloproteinase 9/gelatinase $B$ gene expression in rabbit uterine cervical fibroblasts. Biology of Reproduction $\mathbf{5 6}$ 575-580. (doi:10.1095/biolreprod56.3.575)

Irizarry RA, Hobbs B, Collin F, Beazer-Barclay YD, Antonellis KJ, Scherf U \& Speed TP 2003 Exploration, normalization, and summaries of high density oligonucleotide array probe level data. Biostatistics 4 249-264. (doi:10.1093/biostatistics/4.2.249)

Kalendar R, Lee D \& Schulman AH 2009 FastPCR software for PCR primer and probe design and repeat search. Genes, Genomes and Genomics $\mathbf{1}$ $1-14$.

Kanehisa M, Goto S, Hattori M, Aoki-Kinoshita KF, Itoh M, Kawashima S, Katayama T, Araki M \& Hirakawa M 2006 From genomics to chemical genomics: new developments in KEGG. Nucleic Acids Research $\mathbf{3 4}$ D354-D357. (doi:10.1093/nar/gkj102)

Kidder GM \& Vanderhyden BC 2010 Bidirectional communication between oocytes and follicle cells: ensuring oocyte developmental competence. Canadian Journal of Physiology and Pharmacology $\mathbf{8 8}$ 399-413. (doi:10.1139/Y10-009)

Kim M, Geum D, Khang I, Park YM, Kang BM, Lee KA \& Kim K 2002 Expression pattern of HSP25 in mouse preimplantation embryo: heat shock responses during oocyte maturation. Molecular Reproduction and Development 61 3-13. (doi:10.1002/mrd.1125)

Leber TM \& Balkwill FR 1997 Zymography: a single-step staining method for quantitation of proteolytic activity on substrate gels. Analytical Biochemistry 249 24-28. (doi:10.1006/abio.1997.2170)

Lee DM, Lee TK, Song HB \& Kim CH 2005 The expression of matrix metalloproteinase-9 in human follicular fluid is associated with in vitro fertilisation pregnancy. BJOG: an International Journal of Obstetrics and Gynaecology 112 946-951. (doi:10.1111/j.1471-0528.2005.00574.x)

Lenz RW, Ball GD, Leibfried ML, Ax RL \& First NL 1983 In vitro maturation and fertilization of bovine oocytes are temperature-dependent processes. Biology of Reproduction 29 173-179. (doi:10.1095/biolreprod29.1.173)

Liu K, Wahlberg P \& Ny T 1998 Coordinated and cell-specific regulation of membrane type matrix metalloproteinase 1 (MT1-MMP) and its substrate matrix metalloproteinase 2 (MMP-2) by physiological signals during follicular development and ovulation. Endocrinology 139 4735-4738. (doi:10.1210/en.139.11.4735)

Luciano AM, Lodde V, Beretta MS, Colleoni S, Lauria A \& Modina S 2005 Developmental capability of denuded bovine oocyte in a co-culture system with intact cumulus-oocyte complexes: role of cumulus cells, cyclic adenosine $3^{\prime}, 5^{\prime}$-monophosphate, and glutathione. Molecular Reproduction and Development 71 389-397. (doi:10.1002/mrd.20304)

Marbaix E, Donnez J, Courtoy PJ \& Eeckhout Y 1992 Progesterone regulates the activity of collagenase and related gelatinases $A$ and $B$ in human endometrial explants. PNAS 89 11789-11793. (doi:10.1073/pnas.89.24. 11789)

Matta SG, Caldas-Bussiere MC, Viana KS, Faes MR, Paes de Carvalho CS, Dias BL \& Quirino CR 2009 Effect of inhibition of synthesis of inducible nitric oxide synthase-derived nitric oxide by aminoguanidine on the in vitro maturation of oocyte-cumulus complexes of cattle. Animal Reproduction Science 111 189-201. (doi:10.1016/j.anireprosci.2008. 03.002)

Maya-Soriano MJ, Taberner E \& Lopez-Bejar M 2012 Retinol improves in vitro oocyte nuclear maturation under heat stress in heifers. Zygote 1-8. (doi:10.1017/S0967199412000135)

McKenize KA \& Cohen BD 2009 Investigation of human follicle stimulating hormone residency in membrane microdomains. FASEB Journal $\mathbf{2 3}$ 880.7.

Nabenishi H, Ohta H, Nishimoto T, Morita T, Ashizawa K \& Tsuzuki Y 2012 The effects of cysteine addition during in vitro maturation on the developmental competence. ROS, GSH and apoptosis level of bovine oocytes exposed to heat stress. Zygote 20 249-259. (doi:10.1017/ S0967199411000220)

Nagelkerke NJD 1991 A note on a general definition of the coefficient of determination. Biometrika 78 691-692. (doi:10.1093/biomet/78.3.691) 
Nuttinck F, Charpigny G, Mermillod P, Loosfelt H, Meduri G, Freret S, Grimard B \& Heyman Y 2004 Expression of components of the insulinlike growth factor system and gonadotropin receptors in bovine cumulus-oocyte complexes during oocyte maturation. Domestic Animal Endocrinology 27 179-195. (doi:10.1016/j.domaniend.2004.03.003)

Payne AH \& Hales DB 2004 Overview of steroidogenic enzymes in the pathway from cholesterol to active steroid hormones. Endocrine Reviews 25 947-970. (doi:10.1210/er.2003-0030)

Payton RR, Romar R, Coy P, Saxton AM, Lawrence JL \& Edwards JL 2004 Susceptibility of bovine germinal vesicle-stage oocytes from antral follicles to direct effects of heat stress in vitro. Biology of Reproduction $\mathbf{7 1}$ 1303-1308. (doi:10.1095/biolreprod.104.029892)

Payton RR, Rispoli LA, Saxton AM \& Edwards JL 2011 Impact of heat stress exposure during meiotic maturation on oocytes, surrounding cumulus cell and embryo RNA populations. Journal of Reproduction and Development 57 481-491. (doi:10.1262/jrd.10-163M)

Portela VM, Veiga A \& Price CA 2009 Regulation of MMP2 and MMP9 metalloproteinases by $\mathrm{FSH}$ and growth factors in bovine granulosa cells. Genetics and Molecular Biology 32 516-520. (doi:10.1590/S141547572009005000048)

Putney DJ, Mullins S, Thatcher WW, Drost M \& Gross TS 1989 Embryonic development in superovulated dairy cattle exposed to elevated ambient temperatures between the onset of estrus and insemination. Animal Reproduction Science 19 37-51. (doi:10.1016/0378-4320(89)90045-6)

Qiao TW, Liu N, Miao DQ, Zhang X, Han D, Ge L \& Tan JH 2008 Cumulus cells accelerate aging of mouse oocytes by secreting a soluble factor(s). Molecular Reproduction and Development 75 521-528. (doi:10.1002/ mrd.20779)

Rasband WS 1997-2012 ImageJ. U.S. National Institues of Health, Bethesda, MA, USA, http://imagej.nih.gov/ij.

Regassa A, Rings F, Hoelker M, Cinar U, Tholen E, Looft C, Schellander K \& Tesfaye D 2011 Transcriptome dynamics and molecular cross-talk between bovine oocyte and its companion cumulus cells. $B M C$ Genomics 12 57. (doi:10.1186/1471-2164-12-57)

Ren Y, Cowan RG, Harman RM \& Quirk SM 2009 Dominant activation of the hedgehog signaling pathway in the ovary alters theca development and prevents ovulation. Molecular Endocrinology 23 711-723. (doi:10. 1210/me.2008-0391)

Rensis FD \& Scaramuzzi RJ 2003 Heat stress and seasonal effects on reproduction in the dairy cow - a review. Theriogenology 60 1139-1151. (doi:10.1016/S0093-691X(03)00126-2)

Rispoli LA, Lawrence JL, Payton RR, Saxton AM, Schrock GE, Schrick FN, Middlebrooks BW, Dunlap JR, Parrish JJ \& Edwards JL 2011 Disparate consequences of heat stress exposure during meiotic maturation: embryo development after chemical activation vs fertilization of bovine oocytes. Reproduction 142 831-843. (doi:10.1530/REP-11-0032)

Robert C, Gagne D, Bousquet D, Barnes FL \& Sirard MA 2001 Differential display and suppressive subtractive hybridization used to identify granulosa cell messenger RNA associated with bovine oocyte developmental competence. Biology of Reproduction 64 1812-1820. (doi:10. 1095/biolreprod64.6.1812)

Roth Z \& Hansen PJ 2004 Involvement of apoptosis in disruption of developmental competence of bovine oocytes by heat shock during maturation. Biology of Reproduction 71 1898-1906. (doi:10.1095/ biolreprod.104.031690)

Roth Z \& Hansen PJ 2005 Disruption of nuclear maturation and rearrangement of cytoskeletal elements in bovine oocytes exposed to heat shock during maturation. Reproduction 129 235-244. (doi:10. 1530/rep.1.00394)

Russell DL \& Robker RL 2007 Molecular mechanisms of ovulation: co-ordination through the cumulus complex. Human Reproduction Update 13 289-312. (doi:10.1093/humupd/dml062)

Salhab M, Tosca L, Cabau C, Papillier P, Perreau C, Dupont J, Mermillod P \& Uzbekova S 2011 Kinetics of gene expression and signaling in bovine cumulus cells throughout IVM in different mediums in relation to oocyte developmental competence, cumulus apoptosis and progesterone secretion. Theriogenology 75 90-104. (doi:10.1016/j.theriogenology. 2010.07.014)

Schoenfelder M \& Einspanier R 2003 Expression of hyaluronan synthases and corresponding hyaluronan receptors is differentially regulated during oocyte maturation in cattle. Biology of Reproduction 69 269-277. (doi:10.1095/biolreprod.102.011577)
Schoenfelder M, Schams D \& Einspanier R 2003 Steroidogenesis during in vitro maturation of bovine cumulus oocyte complexes and possible effects of tri-butyltin on granulosa cells. Journal of Steroid Biochemistry and Molecular Biology 84 291-300. (doi:10.1016/S09600760(03)00042-6)

Schrock GE, Saxton AM, Schrick FN \& Edwards JL 2007 Early in vitro fertilization improves development of bovine ova heat stressed during in vitro maturation. Journal of Dairy Science 90 4297-4303. (doi:10.3168/ jds.2007-0002)

Seals RC, Lemaster JW, Hopkins FM \& Schrick FN 1998 Effects of elevated concentrations of prostaglandin $\mathrm{F}_{2 \alpha}$ on pregnancy rates in progestogen supplemented cattle. Prostaglandins and Other Lipid Mediators $\mathbf{5 6}$ 377-389. (doi:10.1016/S0090-6980(98)00063-X)

Shimonovitz S, Hurwitz A, Hochner-Celnikier D, Dushnik M, Anteby E \& Yagel S 1998 Expression of gelatinase B by trophoblast cells: down-regulation by progesterone. American Journal of Obstetrics and Gynecology 178 457-461. (doi:10.1016/S00029378(98)70420-X)

Silva CC \& Knight PG 2000 Effects of androgens, progesterone and their antagonists on the developmental competence of in vitro matured bovine oocytes. Journal of Reproduction and Fertility 119 261-269. (doi:10. 1530/reprod/119.2.261)

Siqueira LC, Barreta MH, Gasperin B, Bohrer R, Santos JT, Buratini J Jr, Oliveira JF \& Goncalves PB 2012 Angiotensin II, progesterone, and prostaglandins are sequential steps in the pathway to bovine oocyte nuclear maturation. Theriogenology 77 1779-1787. (doi:10.1016/j. theriogenology.2011.12.022)

Sirotkin AV 1992 Involvement of steroid hormones in bovine oocytes maturation in vitro. Journal of Steroid Biochemistry and Molecular Biology 41 855-858. (doi:10.1016/0960-0760(92)90438-O)

Smyth GK 2004 Linear models and empirical bayes methods for assessing differential expression in microarray experiments. Statistical Applications in Genetics and Molecular Biology 3 Article3. (doi:10.2202/1544-6115. 1027)

Sternlicht MD \& Werb Z 2001 How matrix metalloproteinases regulate cell behavior. Annual Review of Cell and Developmental Biology 17 463-516. (doi:10.1146/annurev.cellbio.17.1.463)

Tosca L, Uzbekova S, Chabrolle C \& Dupont J 2007 Possible role of $5^{\prime}$ AMP-activated protein kinase in the metformin-mediated arrest of bovine oocytes at the germinal vesicle stage during in vitro maturation. Biology of Reproduction 77 452-465. (doi:10.1095/biolreprod.107. 060848)

Toth M \& Fridman R 2001 Assessment of gelatinases (MMP-2 and MMP-9) by gelatin zymography. In Metastasis Research Protocols, vol 1: Analysis of Cells and Tissues, Methods in Molecular Medicine, vol 57, pp 163-174. Eds SA Brooks \& U Schumacher. Totawa, NJ, USA: Humana Press.

Tsafriri A, Vale W \& Hsueh AJ 1989 Effects of transforming growth factors and inhibin-related proteins on rat preovulatory Graafian follicles in vitro. Endocrinology 125 1857-1862. (doi:10.1210/endo125-4-1857)

Van den Steen PE, Dubois B, Nelissen I, Rudd PM, Dwek RA \& Opdenakker G 2002 Biochemistry and molecular biology of gelatinase B or matrix metalloproteinase-9 (MMP-9). Critical Reviews in Biochemistry and Molecular Biology 37 375-536. (doi:10.1080/ 10409230290771546)

Weber PSD, Madsen-Bouterse SA, Rosa GJM, Sipkovsky S, Ren X, Almeida PE, Kruska R, Halgren RG, Barrick JL \& Burton JL 2006 Analysis of the bovine neutrophil transcriptome during glucocorticoid treatment. Physiological Genomics 28 97-112. (doi:10.1152/physiolgenomics.00094.2006)

Wijgerde M, Ooms M, Hoogerbrugge JW \& Grootegoed JA 2005 Hedgehog signaling in mouse ovary: Indian hedgehog and desert hedgehog from granulosa cells induce target gene expression in developing theca cells. Endocrinology 146 3558-3566. (doi:10.1210/ en.2005-0311)

Wolfenson D, Lew BJ, Thatcher WW, Graber Y \& Meidan R 1997 Seasonal and acute heat stress effects on steroid production by dominant follicles in cows. Animal Reproduction Science 47 9-19. (doi:10.1016/S03784320(96)01638-7) 
Wu Z, Irizarry RA, Gentleman R, Martinez-Murillo F \& Spencer F 2004 A model-based background adjustment for oligonucleotide expression arrays. Journal of the American Statistical Association 99 909-917. (doi:10.1198/016214504000000683)

Yamashita Y, Shimada M, Okazaki T, Maeda T \& Terada T 2003 Production of progesterone from de novo-synthesized cholesterol in cumulus cells and its physiological role during meiotic resumption of porcine oocytes. Biology of Reproduction 68 1193-1198. (doi:10.1095/biolreprod.102.010934)

Yu Q \& Stamenkovic I 2000 Cell surface-localized matrix metalloproteinase-9 proteolytically activates TGF- $\beta$ and promotes tumor invasion and angiogenesis. Genes and Development 14 163-176. (doi:10.1101/gad. 14.2.163)

Yuan Y, Hao ZD, Liu J, Wu Y, Yang L, Liu GS, Tian JH, Zhu SE \& Zeng SM 2008 Heat shock at the germinal vesicle breakdown stage induces apoptosis in surrounding cumulus cells and reduces maturation rates of porcine oocytes in vitro. Theriogenology 70 168-178. (doi:10.1016/j. theriogenology.2008.03.005)

Zhang L, Jiang S, Wozniak PJ, Yang X \& Godke RA 1995 Cumulus cell function during bovine oocyte maturation, fertilization, and embryo development in vitro. Molecular Reproduction and Development $\mathbf{4 0}$ 338-344. (doi:10.1002/mrd.1080400310)

Received 3 December 2012

First decision 4 January 2013

Revised manuscript received 3 May 2013

Accepted 6 June 2013 